Rhode Island College

Digital Commons @ RIC

\title{
Ventilator-Associated Pneumonia and the Effectiveness of Endotracheal Tubes Coated with Silver Sulfadiazine
}

Nathaniel Van Hueveln

Follow this and additional works at: https://digitalcommons.ric.edu/etd

Part of the Other Nursing Commons

\section{Recommended Citation}

Van Hueveln, Nathaniel, "Ventilator-Associated Pneumonia and the Effectiveness of Endotracheal Tubes Coated with Silver Sulfadiazine" (2017). Master's Theses, Dissertations, Graduate Research and Major Papers Overview. 251.

https://digitalcommons.ric.edu/etd/251

This Major Paper is brought to you for free and open access by the Master's Theses, Dissertations, Graduate Research and Major Papers at Digital Commons @ RIC. It has been accepted for inclusion in Master's Theses, Dissertations, Graduate Research and Major Papers Overview by an authorized administrator of Digital Commons @ RIC. For more information, please contact digitalcommons@ric.edu. 


\title{
VENTILATOR-ASSOCIATED PNEUMONIA AND THE EFFECTIVENESS OF ENDOTRACHEAL TUBES COATED WITH SILVER SULFADIAZINE
}

\author{
by
}

Nathaniel Van Heuveln

A Major Paper Submitted in Partial Fulfillment

of the Requirements for the Degree of

Master of Science in Nursing

in

The School of Nursing

Rhode Island College

2017 


\begin{abstract}
Ventilator-associated pneumonia (VAP) is a consequence of intubation and mechanical ventilation. Bacteria colonize the inner-lumen of endotracheal tubes (ETT) and develop into a biofilm. One method to reduce/eliminate the develop of biofilms within the ETT is lining the inner-lumen with silver-sulfadiazine. A systematic review was conducted to evaluate the effectiveness of silver-coated ETTs for patients that develop VAP. Multiple databases were searched to identify key literature related to silver-coated ETTs and VAP. Inclusion and exclusion criteria were identified to finalize the studies that were included in this systematic review. Five key studies were included in this review. Studies were further evaluated with PRISMA, a data collection table, the Critical Appraisal Skills Programme (CASP) and the Critical Appraisal for Summaries of Evidence (CASE) worksheet. All studies found either a reduction or elimination of bacteria within the ETT, breathing circuit, or lungs of the study subjects. In addition to the reduced colonization found across the studies, one study found a reduction in the mortality rate for the intervention group following a diagnosis of VAP. Certified Registered Nurse Anesthetists (CRNA) play an important role in educating staff about the impact silvercoated ETTs have on patient outcomes throughout periods of intubation and mechanical ventilation. Additionally, CRNAs are well positioned to identify patients pre-operatively that may require prolonged intubation following surgery. By advocating for silver-coated ETTs for these patients, CRNAs can improve patient outcomes by reducing the likelihood of these patients developing VAP.
\end{abstract}




\section{Table of Contents}

Background/Statement of the Problem.........................................

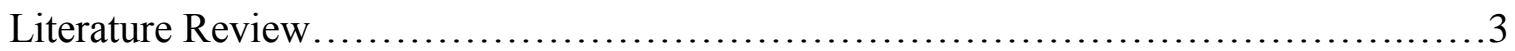

Theoretical Framework........................................................ 13

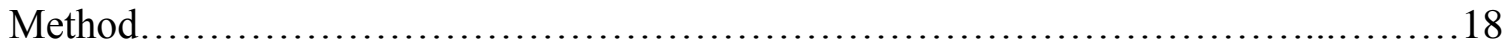

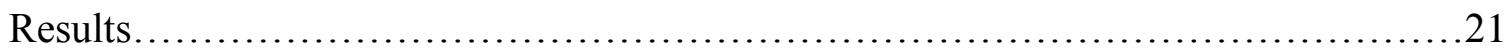

Summary and Conclusions.................................................. 33

Recommendations and Implications for Advanced Nursing Practice...................36

References............................................................. 39

Appendices.................................................................... 44 
Ventilator-Associated Pneumonia and the Effectiveness of Endotracheal Tubes Coated with Silver Sulfadiazine

\section{Background/Statement of the Problem}

Ventilator-associated pneumonia (VAP) occurs when patients are mechanically ventilated and become colonized with bacteria in their endotracheal tube (ETT) that originates from an external source or gastric content. Miller et al. (2014) defined VAP as occurring when a patient requiring mechanical ventilation develops a new lower respiratory infection. Endotracheal tubes increase the risk of developing pneumonia by suppressing innate protective airway reflexes (Miller et al.). Patients who develop VAP have increased length of hospitalizations and are intubated for a greater number of days. Additionally, those who develop VAP have more expensive hospitalizations, require a greater number of services from the multi-disciplinary hospital care teams and have a higher mortality rate than patients who do not develop VAP (Mietto, Pinciroli, Patel, \& Berra, 2013). Diagnosis of VAP includes a combination of new or persistent infiltrates on chest radiography and two of the following: temperature greater than 38.3 , blood leukocytosis (>12 $\times 10^{9}$ white blood cells/liter) or purulent tracheal secretions (Hunter, 2012).

The use of silver for treatment of bacterial infections, wounds and injuries is well established. However, during the past several decades, its' use has declined due to the development and availability of antibiotics (Rai, Yadav, \& Gade, 2008). As bacteria become increasingly resistant and harder to treat, silver's antimicrobial properties have resurfaced as a viable option for the treatment and prevention of infections throughout the medical field. 
One of the most frequently implicated sources of VAP are biofilms, which form on the inner-lumen of the ETT and have unimpeded access to patients' lungs. Innovations to the design and composition of ETTs are being studied to determine efficacy in minimizing the development of VAP and biofilms. Endotracheal tubes that utilize the impregnation or coating of silver sulfadiazine are designed to reduce the incidence of VAP by preventing the development of biofilm (Afessa et al., 2010).

Silver ions, with their ability to bind and oxidize Thiol groups and disrupt the development of respiratory-chain proteins, has been applied to ETTs as a treatment strategy to prevent bacterial colonization (Pirrone, Pinciroli, \& Berra, 2016). Technological advances in the field of nanomedicine has renewed interest in metal impregnation, primarily silver, into medical devices (Palanisamy et al., 2014). There is ongoing research involving the antimicrobial effects of silver on well known bacteria such as Escherichia coli, Staphylococcus Aureus, and Pseudomonas Aeruginosa. The relationship between silver and nanomedicine uncovered direct links to the treatment of bacteria related to the size, shape, and composition of the silver particles' efficacy of silver products on specific bacteria (Ge, Li, Wang, Ouyang, Li, \& Xing, 2014).

The purpose of this systematic review was to examine the impact of ETTs impregnated with silver sulfadiazine on patient's with VAP. The results will be compared to the incidence of VAP for patients with traditional polyvinyl-chloride ETTs.

Next, the review of the literature will be presented 


\section{Literature Review}

The review of literature was performed by accessing the databases Cumulative Index to Nursing and Allied Health Literature (CINAHL), OVID and PubMed. Keywords used were ventilator-associated pneumonia, VAP, silver sulfadiazine, ETT, silver-coated endotracheal tubes and biofilm. Dates searched were between 2006 and 2017.

\section{Incidence and Cost of VAP}

The incidence of VAP is estimated to be $1.2 \%-8.5 \%$ per 1,000 ventilator days with the greatest risk of developing VAP during the first five days of intubation (Kalanuria, Zai, \& Mirski, 2014). Treatment and staffing for VAP are substantial. Shorr, Zilberberg, \& Kollef found that it cost $\$ 12,840$ for each patient diagnosed with VAP. Zimlichman et al. suggested the development of VAP, which is the second most expensive nosocomial infection, cost \$40,144 (2013).

Prevention of VAP is a national patient safety standard. The Centers for Medicare and Medicaid services has proposed non-reimbursement for healthcare centers where patients are diagnosed with VAP (Mietto, Pinciroli, Patel, \& Berra, 2013).

\section{Ventilator-Associated Pneumonia and Intubation}

The development of VAP occurs mainly from the ETT obstructing the body from coughing to protect itself (Kalanuria et al., 2014). The body's inability to expectorate potentially infectious pathogens allows them to penetrate deep into the oropharynx. Ventilator-associated pneumonia is described by Kalanuria et al. as a "complex interplay between the endotracheal tube, patient risk factors, virulence of invading organisms, and the host's immunity" (p. 1). Additional contributing factors include supine positioning, 
enteral feedings through naso/orogastric tubes and trauma (Hunter, 2012). One of the common sources of bacterial introduction to the lungs occurs during direct laryngoscopy, which leads to micro-aspiration (Kalanuria et al., 2014).

Following intubation, the cough reflex of the glottis and larynx is inhibited. Pathogens located within the oral cavity start to adhere to the inner lumen of the standard polyvinyl chloride (PVC) ETT. When patients remain intubated and ventilated, bacteria begin to form a microfilm within the ETT which ultimately develops into an endoluminal biofilm. These pathogens, some of which can lead to VAP, migrate to the lower respiratory tract (Pirrone et al., 2016).

Following cuff inflation of the ETT, secretions begin to pool in the subglottic area surrounding the cuff and ultimately seep into the lungs (Kalanuria et al., 2014). The secretions constantly ooze around the cuff through microscopic folds known as microchannels (Pirrone et al., 2016). The combination of endoluminal biofilms and pathogenic secretions leaking into the lower respiratory tract via micro-channels significantly increase the risk of VAP.

One of the key determinants in a pathogen's etiology of VAP is the length of time the patient has been intubated. Kalanuria et al. (2014) found that patients diagnosed with VAP shortly after intubation were more sensitive to antibiotics. Patients diagnosed with late-onset VAP were more difficult to treat because the causative pathogens were often multi-drug resistant. Streptococcus Pneumonia, Hemophilus Influenza, Methicillinsensitive Staphylococcus Aureus (MSSA), Escherichia Coli and Klebsiella Pneumonia were identified as common pathogens found in early-onset VAP (Kalanuria et al.). Common pathogens identified for late-onset VAP include Methicillin-resistant Staph 
Aureus (MRSA), Pseudomonas Aeruginosa, and Extended-Spectrum Beta-Lactamase (ESBL) (Kalanuria et al.).

Prevention and diagnosis of VAP remain challenging for medical professionals. One of the challenges in diagnosing VAP is that there is no recognized diagnostic gold standard. Bedside evaluation and chest $\mathrm{x}$-ray are effective diagnostic tools but are not definitive (Kalanuria et al., 2014). Although chest x-rays are frequently used as a diagnostic tool for VAP, other conditions such as acute respiratory distress syndrome (ARDS), congestive heart failure (CHF) and aspiration pneumonitis have similar radiological appearances. The recommendation for diagnosis of VAP by the Infectious Diseases Society of America (IDSA) and the American Thoracic Society (ATS) is to obtain and culture tracheal aspirates or lower respiratory tract samples (Kalil et al., 2016).

The leading strategy for prevention of VAP remains VAP bundles (Hunter, 2012). Ventilator associated pneumonia bundles are evidence-based interventions that promote a prophylactic approach to preventing VAP by reducing the likelihood of aspirating contaminated secretions and limiting the pulmonary colonization of bacteria. Ventilator associated pneumonia bundles include elevation of the head of the bed, prophylaxis stress ulcer medication, deep venous thrombosis prophylaxis, oral care with chlorhexidine and daily sedation assessments that monitor breathing status (Kalanuria et al., 2014). In addition to basic VAP bundles, some additional strategies to reduce VAP include thorough oral care every 2-4 hours with chlorhexidine, frequent oropharyngeal suctioning, inline ETT suctioning, and removal of condensation that develops throughout the ventilator circuit (Miller et al., 2014). 
Due to the significant morbidity and mortality of VAP, the Institute for Healthcare Improvement (IHI) created a campaign in 2005 called the 100,000 lives campaign that included implementing VAP bundles as one of the core initiatives to minimize adverse patient outcomes. The IHI's goal was to save 100,000 lives in 18 months through six evidence-based clinical interventions (IHI, n.d.). During a follow up study to the 100,000 lives campaign (2009), Bigham et al. concluded that there had been significant reductions in VAP, length of intubation and mechanical ventilation and length of hospital stay since the implementation of VAP bundles. As a result of the IHI's successful campaign to prevent incidences of medical harm and to improve patient health outcomes, the campaign expanded its goal to 5,000,000 (IHI, n.d.). Despite the belief by medical experts that the campaign was successful, the IHI has not been able to accurately calculate and quantify the data (IHI, n.d.). The IHI continues to stress the need for hospital compliance with VAP bundles (Kalanuria et al., 2014).

A new proposal that has gained traction in VAP prevention is single dose antibiotic therapy within four hours of intubation (Kalanuria et al., 2014). While this strategy has spurred interest, no randomized clinical trials have been completed to support the theory that it could reduce VAP. As the research surrounding VAP advances, the focus on prevention has grown to include strategies to minimize its morbidity, mortality, and impact on the health care system. One key area of research regarding VAP reduction is silver technology. Silver's well established use as an antimicrobial and treatment option for burns has advanced into a multitude of silver products. 


\section{Silver Sulfadiazine and General Medical Use}

One of the roles of silver in healthcare is to minimize the potential of infection associated with medical devices. Nearly half of all nosocomial infections are caused by hip prosthetics, vascular and urinary catheters, and ETTs (Monteiro et al., 2009). Due to increasing rates of nosocomial infections and drug resistant bacteria, silver has seen renewed interest and implementation within the medical field (Wan et al., 2016). Advancements in nanotechnology and infectious disease research have shown increasingly effective treatment for highly resistant infections, such as carbapenemresistant, by adding silver nanoparticles to antibiotic regimens (Wan et al.). The addition of silver also allows providers to dose patients' antibiotics more conservatively. Lower doses of antibiotics reduce the likelihood that a patient will receive harmful or toxic doses or antibiotics.

The antimicrobial properties of silver have been used to treat burn injuries for more than 200 years (Marx \& Barillo, 2014). Silver inhibits bacteria by binding to the base pairs of the DNA helix (Rai et al., 2009) which prevents transcription and causes damage to the cell membrane. Silver, in particular Nanosilver particles (NSP), have broad antimicrobial properties against both gram negative and gram positive bacteria (Ge et al., 2014). Nanoparticles are small clusters of atoms ranging from 1-100 nanometers (Rai et al., 2009). Nanosilver particles can be impregnated into medical devices, nanogels and nanolotions. Nanosilver particles are used for diagnosis, drug delivery and treatment of infections. In addition to NSPs antibacterial qualities, silver has also been used as an antiviral, antifungal, and anti-inflammatory (Ge et al., 2014). The key factors 
that influence the efficacy of silver particles as an antimicrobial agent include size, shape (rods, particles, plates), and concentration (Ge et al.).

Other promising silver products besides NSPs include silver zeolite (SZ) and products that release silver in their oxidized form (Monteiro et al., 2009). Silver ions are very effective at inhibiting bacterial growth by inactivating the Thiol group within a protein. The ions disrupt DNA replication by disrupting the transport chain and uncoupling the oxidative phosphorylation leading to complications with cell permeability (Duran et al., 2016). Silver zeolites provide a large surface area that makes ion release much easier to control (Leyland et al., 2016). Additionally, the total amount of silver in the zeolites is modest which makes it financially reasonable as an adjunct/form of treatment.

Nanomedicine, including NSPs, is an important trend in modern medical treatment. Due to its emergence as an adjunct or alternative to certain antibiotic treatments, silver nanomedicine has drawn the interest of many scientific and infection control specialists (Franci et al., 2015). The importance of nanotechnology and silver is that they possess a large surface to area to volume ratio (Rai et al., 2009). The surface to volume ratio makes nanoparticles increasingly intriguing for researchers who study treatment modalities for microbes that are resistant to metal ions (Rai et al.). This ratio creates an effective treatment strategy against bacteria. Released silver ions possess significant antimicrobial properties in vivo and in vitro.

One limitation to the effectiveness of silver for use as an antimicrobial is that it has a concentration-dependent toxicity for humans (Brandt et al., 2012). Percutaneous absorption of silver can lead to argyria. Argyria is a local or systemic tissue deposition of 
silver (heavy metal) in organs such as the liver, spleen or kidney or nerves that can lead to organ failure (Brandt et al.). Another limitation is microbial resistance to silver. Several silver resistant bacteria have been identified globally throughout India, Utah, and the United Kingdom (Duran et al., 2015). Overuse of silver nanoparticles as an antimicrobial could lead to a new generation of microbial resistance.

\section{Silver Coated Endotracheal Tubes (ETT) and VAP}

Biofilms are antimicrobial resistant areas of bacterial colonization that proliferate in moist areas (Monteiro et al., 2009). Biofilm leads to VAP by creating a network of secretions and attached microorganisms capable of migrating along the ETT cuff polymer down the inner lumen of the ETT (Fernandez, Levine, \& Restrepo, 2012). Biofilms are a target area of study for silver scientists. Fernandez et al. described why biofilm research is critical to reducing VAP. A characteristic of biofilms that makes them amenable to treatment with silver is that they are capable of extracting minerals and metals up to a quantifiable absorption capacity. Factors that are used to quantify absorption capacity and binding affinity are the size/charge ratio, the bacterial polysaccharide charge, the $\mathrm{pH}$, and the biofilm (Moneiro et al., 2009). As the biofilm absorbs the silver, its development is inhibited.

One of the key pieces of literature and landmark studies related to silver sulfadiazine and ETTs was The North American Silver-Coated Endotracheal Tube (NASCENT) Randomized Trial (Kollef et al., 2008). This prospective, randomized, single-blind trial was conducted in North America between 2002-2006 and involved 54 locations and 2,003 patients that required mechanical ventilation for a minimum of 24 hours. The primary outcome measure for the study was incidence of VAP. 
The only inclusionary criteria was that patients had be at least 18 years-old and required intubation for at least 24 hours. Exclusionary criteria included current participation in another study, cystic fibrosis, hemoptysis, pregnancy, silver sensitivity and intubation within the past 30 days. Screening for the trial included 9,417 potential participants. Screening and data collection focused on patients' demographics, medical history, immunocompetency and Acute Physiology and Chronic Health Evaluation (APACHE) II. The APACHE II is a scoring system used in intensive care units (ICU) that classifies each patient's severity of illness. Of the 9,417 patients screened, 7,414 were deemed ineligible. Of the remaining 2,003, 71 ended up not requiring intubation and 423 were intubated for less than 24 hours. Each patient was intubated with a high volume-low pressure ETT. During the study, specific patient data collection included daily chest radiographs, clinical signs of VAP, adverse events, length of stay in the ICU and hospital, mortality, antibiotics used during bronchoalveolar lavage (BAL), oral care, tracheal suctioning and method of nutrition delivery (Kollef et al.).

Results from the study identified a relative risk reduction in VAP of $34.2 \%$ for patients intubated with ETTs coated with silver sulfadiazine (Kollef et al., 2008). Of the patients intubated with the silver-coated ETT, $4.8 \%$ were diagnosed with VAP (37/766). Patients with the uncoated-traditional ETT were diagnosed with VAP $7.5 \%$ of the time (56/743). The findings were supported by a $95 \%$ confidence interval (CI) and a $90 \%$ statistical power. Secondary findings by Kollef et al. included a delayed occurrence of VAP as well as a relative risk reduction in the frequency of VAP diagnosed for patients intubated with silver-coated ETTs for greater than 10 days. Patients with the silvercoated ETTs had a mortality rate of 30.4\% (233/766) while patients intubated with 
standard ETTs had a mortality rate of $26.6 \%$ (198/743). Interestingly, there was no statistical difference in the frequency or severity of adverse events in in either group (Kollef et al.).

Another key piece of literature involving silver-coated ETTs is the Association Between a Silver-Coated Endotracheal Tube and Reduced Mortality in Patients with Ventilator-Associated Pneumonia by Afessa et al. (2010). In this retrospective study of the NASCENT randomized trial, Afessa et al. analyzed the data from the NASCENT study. The purpose was to identify an association between decreased mortality in patients diagnosed with VAP when silver-coated ETTs were used compared to traditional ETTs.

The results supported the original findings from the NASCENT study. Afessa et al. (2010) concluded that ETTs impregnated with silver sulfadiazine not only reduced incidences of VAP, but it also reduced mortality in patients with VAP. The mortality rate for patients diagnosed with VAP that had silver-coated ETTs was 5 out of 37 (14\%) while the mortality rate for patients without the silver-coated ETT was 20 out of 56 (36\%). The $\mathrm{P}$ value for the findings was 0.03 . This implies a significant difference in patient outcomes based on what type of ETT was used. The mortality rate for the patients who did not have VAP was 228/729 (31\%) for patients with the silver-coated ETTs and 178/687 (26\%) for patients without the silver-coated ETTs. Although no significant conclusions were made regarding mortality in the group that did not develop VAP, respiratory failure, multi-organ failure, and sepsis were most frequently cited as their cause of death (Afessa et al.). 
Studies involving silver coated ETTs are limited. However, there have been several in vitro and animal studies. Many of the in vitro and animal studies have shown effective preventative strategies and antimicrobial properties with silver.

Next, the theoretical framework that guided the project will be discussed. 


\section{Theoretical Framework}

The Preferred Reporting Items for Systematic Review and Meta-Analysis

Protocols (PRISMA-P) is a data reporting system used for systematic reviews. The goal of PRISMA is to provide both the reader and the researcher/author transparency and consistency while evaluating data for both systematic reviews and meta analysis.

Systematic reviews and meta-analyses are considered by many to be the gold standard for collection, interpretation, and dissemination of research in health care (Moher, Liberati, Tetzlaff, \& Altman, 2009). Systematic reviews are becoming increasingly common throughout healthcare due to their methodological rigor (Moher et al., 2015). As of 2010, 11 new systematic reviews were published daily (Moher et al., 2015).

In 1999, before PRISMA-P, the Quality of Reporting of Meta-Analysis (QUOROM) was developed in response to suboptimal reporting of meta-analyses (Moher et al., 2009). The QUOROM statement was developed by an international group who believed that prior systematic reviews and meta-analyses were of inferior quality and poorly presented. As systematic reviews and meta-analyses became more popular, the QUOROM statement was redesigned into PRISMA.

The Preferred Reporting Items for Systematic Review and Meta-Analysis was originally designed in 2005 for authors who needed a consistent framework to collect and report data from systematic reviews and meta-analysis. Improved reporting through PRISMA helped readers with decision making and clarity to evaluate the quality of research being presented (Moher et al., 2009). One aspect of systematic reviews that was felt to be lacking throughout research in healthcare was clarification and consistency. Protocols identified by PRISMA aimed to help authors clarify and identify relevant topics 
and explicitly document on their specified topics (Moher et al.). As a result, PRISMA lead to more consistency, integrity, and accountability (Moher et al.).

The Preferred Reporting Items for Systematic Review and Meta-Analysis incorporates a 27 item checklist to guide researchers and minimize bias in data compilation. The checklist includes seven major headings that consist of title, abstract, introduction, methods, results, discussion, and funding. The checklist allows researchers to compile data in a consistent and transparent format. The Preferred Reporting Items for Systematic Review and Meta-Analysis was used to guide the researcher through the process of completing a thorough systematic review.

The author reviewed the 27 item checklist created by PRISMA to organize and compile data. The organization and compilation of data provided in-depth extrapolation of findings for the reader. For example, data gathered by the author for the results section will inform readers of each studies characteristics, potential bias, and individual results. The author identified limitations of each study and completed the critical appraisal process.

The Preferred Reporting Items for Systematic Review and Meta-Analysis also contains a flowchart (Figure 1) to aid researchers throughout their literature review process for evaluation of research as it relates to specific topics. The flowchart provides readers with a visual as to how the data is collected and utilized. Each phase of process including identification, screening, eligibility, and inclusion are clearly documented for the reader.

The critical appraisal was completed by using the tool created by the Better Value Healthcare Ltd (BVHC) called the Critical Appraisal Skills Programme (CASP). The 
CASP was created by a group from Oxford, England which focuses on value based healthcare for individuals and organizations. The group, also known as the Public Health Resource Unit, is part of the National Health Service (NHS) in England. The Critical Appraisal Skills Programme was designed to aide professionals who desire to use research in their professional practice. Additionally, CASP can be used to help develop guidelines and industry policy. One key focus of CASP is to help readers better understand and utilize scientific data/results. The BVHC provides training courses, education and training materials, and works with healthcare providers to improve their understanding and value related to patient care.

The Critical Appraisal Skills Programme can aide and expedite the researcher who is compiling data during a systematic review by asking three straight-forward questions:

1). Is the study valid?

It is important to identify if there was any bias in the study. One of the most effective methods to identify bias in a study is to analyze the quality of the methods used.

2). What are the results?

If the study is determined to be valid, the results may be considered. When reviewing the results, it is imperative to identify any ambiguity in the findings. Additionally, the results should be examined for clinical significance. 3). Are the results useful?

If the study is unbiased and the results are valid, a determination must be made regarding the usefulness of the results. A determination must be made regarding the 
application of the findings to the author's original question. These three questions help researches quickly critically appraise research and make their own determination of the studies quality.

If the study is determined to be valuable, CASP identifies an additional 10 questions that help the researcher systematically analyze each study. The first two questions are screening questions. If the answer to both of the first questions is "yes," the researcher should continue with the remaining questions.

1. Did the review address a clearly focused question?

2. Did the authors look for the right type of papers?

3. Do you think all the important, relevant studies were included?

4. Did the review's authors do enough to assess the quality of the included studies?

5. If the results of the review have been combined, was it reasonable to do so?

6. What are the overall results of the review?

7. How precise are the results?

8. Can the results be applied to the local population?

9. Were all important outcomes considered?

10. Are the benefits worth the harms and costs?

The cross study analysis was further clarified by utilizing the Critical Appraisal for Summaries of Evidence (CASE) worksheet for systematic reviews. This tool, created by Foster and Shurtz in 2013, was designed to systematically assess the overall quality of evidence presented in each study. Pertinent topics covered in the worksheets include topic, method, content, and application to practice. 
Next, the study methods will be described. 


\section{Method}

\section{Purpose}

The purpose of this systematic review was to examine the impact of ETTs impregnated with silver sulfadiazine on patient's with VAP.

\section{Inclusionary and Exclusionary Criteria}

Inclusion criteria included: human subjects that are at least 18 years-old who were intubated for a minimum of 24 hours in an ICU; all specialty care ICUs except pediatric and neonatal; ETTs must have been coated or impregnated with silver sulfadiazine in an intervention group with uncoated ETTs in a control group; must have been diagnosed with VAP. Animal studies involving intubations with silver coated ETTs were also included. Animal trials were included due to their similarities in study design and controls that paralleled human trials. The author focused primarily on randomized controlled trials (RCT). No limitations were set for dates of articles. Only articles available in English were included.

Exclusionary criteria included patients with significant hemoptysis (hemoptysis automatically places patients at high risk for aspiration and the development of pneumonia), patients who were previously intubated within the past 30 days (they are respiratory compromised) and patients intubated for 14 days or greater.

\section{Data Collection Strategy}

Data collection included information specific to the study design (Table 1). These pieces of data were collected and organized using a tool to provide a clear and concise visualization for the author when referencing key literature. Data collection also included data that focused on study outcomes. The collection and sorting process helped guide the 
author so that studies could be quickly referenced. Breaking down the data provided the author a clear way to compare and contrast the studies throughout the data synthesis

Table 1

Data Collection Template

\begin{tabular}{|c|c|c|c|c|c|c|}
\hline Design & $\begin{array}{l}\text { Site } \\
\text { Sample } \\
\text { (age, } \\
\text { number of } \\
\text { participants } \\
\text {-how they } \\
\text { were } \\
\text { selected, } \\
\text { human or } \\
\text { animal } \\
\text { subjects) }\end{array}$ & $\begin{array}{l}\text { Patient risk } \\
\text { factors } \\
\text { prior to } \\
\text { intubation } \\
\text { (i.e. } \\
\text { existing } \\
\text { heart } \\
\text { disease, } \\
\text { immunode- } \\
\text { ficiency, } \\
\text { chronic } \\
\text { obstructive } \\
\text { pulmonary } \\
\text { disease } \\
\text { (COPD) }\end{array}$ & $\begin{array}{l}\text { Duration } \\
\text { of } \\
\text { Intubation }\end{array}$ & $\begin{array}{l}\text { Was the } \\
\text { ETT coated } \\
\text { or } \\
\text { impregnated } \\
\text { with silver } \\
\text { sulfadiazine } \\
\text { or was it an } \\
\text { uncoated } \\
\text { ETT? }\end{array}$ & $\begin{array}{l}\text { Outcomes of } \\
\text { intubation? } \\
\text { Mortality rate } \\
\text { for } \\
\text { participants } \\
\text { diagnosed } \\
\text { with VAP. }\end{array}$ & Limitations \\
\hline
\end{tabular}

The author critically analyzed the selected studies with the CASP tool for systematic reviews. The author focused on such items as the quality of the study design, quality of data, the relevance of the data and the implications of how the data can be used. 
The goal of the data synthesis was to provide a method for the author to look across the studies and determine if commonalities or variations were found throughout the available data. The Critical Appraisal for Summaries of Evidence (CASE) worksheet for systematic reviews was used to compare across studies. The author then examined across all studies to identify commonalities and variances throughout the descriptive data synthesis. It was critical to determine if the results of the studies supported or refuted each other.

Next, the study results are presented. 


\section{Results}

Based on the inclusion and exclusion criteria, the systematic review included five studies. The pathway that resulted in the selection of the studies is illustrated in Figure 1.

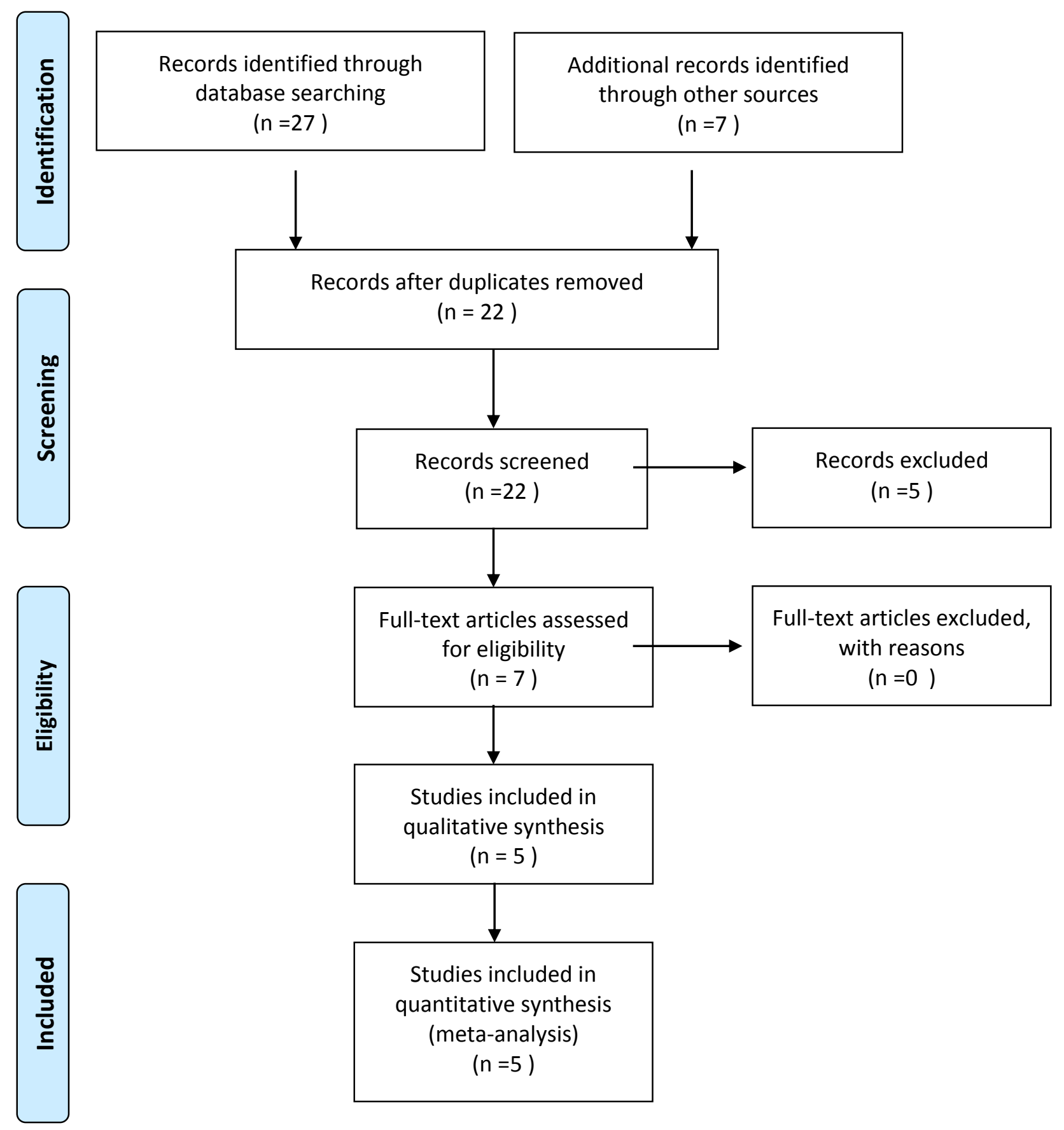

Figure 1. The Preferred Reporting Items for Systematic Reviews and Meta-Analysis Flow Diagram. 
The data collection tables are presented in Appendix A, with each of the five studies individually numbered. The critical appraisal of each study is presented in Appendix B.

The study conducted by Berra et al. (2004; Appendix A-1) was a randomized controlled trial conducted at the National Institutes of Health Animal Research Laboratory in Bethesda, Maryland. The authors examined whether or not ETTs coated with antiseptics (silver) would decrease bacterial colonization of ventilator circuits, lungs, and ETTs. Subjects were female Dorset sheep $(\mathrm{N}=16)$ that were intubated for 24 hours and ranged in weight from $25-37 \mathrm{~kg}$. The intervention group $(\mathrm{n}=8)$ were intubated with silver-coated ETTs and the control group $(n=8)$ were intubated with standard ETTs. Each subject was considered to be in optimum health prior to the study. Based on laboratory data and chest radiographs taken three days before the start of the study, no predetermined risk factors were identified. No antibiotics had been given to the subjects within four weeks of the study's start.

Each subject was successfully intubated on the first attempt. Subjects were placed in the prone position during the 24-hour mechanical ventilation period. Throughout the study, the subjects were monitored for respiratory and hemodynamic parameters/changes, core body temperature, arterial blood gases, and urine output. Microbiologic sampling was conducted every eight hours and included blood samples and a swab of the internal lumen of the ETT. Mucus and secretions gathered from the ETT were gram-stained and analyzed with light microscopy. During the study, subjects were afebrile and not found to have developed leukocytosis or changes in chest 
radiographs. No parenteral nutrition, IV fluid replacement, or antibiotics were administered during the study.

Results of the study were collected from autopsy and the subject's equipment (ETT and ventilator circuit). Tissue samples were gathered from the trachea, larynx, bronchi and the five lung lobes of each subject. Of the subjects with the silver-coated ETTs (intervention group), seven out of eight were free of bacterial colonization throughout the ETT. The subjects intubated with standard ETTs (control group) had extensive bacterial colonization of their lower respiratory tract, ETT and ventilator circuit. Multiple bacterial species were found in the tracheal-bronchial tree and lungs of both groups. The bacteria were found in three out of eight in the intervention group and seven out of eight in the control group were colonized $(\mathrm{P}=0.119)$.

One of the limitations to extrapolating further data from this study was that all subjects were euthanized following the 24 hours of mechanical ventilation. Due to the euthanization, readers can only speculate which of the subjects would have developed VAP. While the likelihood is high that all the bacterially colonized subjects would have developed VAP, no conclusions can be made.

This study was critically appraised using the CASP tool (Appendix B-1). The study addressed a specific question regarding effectiveness of silver-coated ETTs and bacterial colonization of the lungs, ETT and ventilator circuit. The study appropriately randomized subjects and blinded staff involved with the study. Subjects were similar in overall health at the start of the study, treatments were consistent between both the control and intervention groups, and all were accounted for in the results. No treatment effect was documented. Although the study participants were sheep, the results were 
comparable to those of human studies. All important outcomes were identified and considered during the study. Although the data gathered from the study supported similar studies, it is unclear if the harms/costs of the study were beneficial because all participants were euthanized following the 24 hours of mechanical ventilation.

The study conducted by Berra et al. (2008; Appendix A-2) was a randomized controlled trial that was performed on eight Dorset sheep that were mechanically ventilated for a period of 24 hours. All study participants were deemed healthy prior to the study. Each had undergone multiple screening tests including labs, chest radiographs and clinical examinations. Additionally, each was intubated successfully on the first attempt. The study was conducted in a laboratory at the National Institute of Health in Bethesda, Maryland. Four sheep were intubated with silver-coated ETTs (intervention group) and the remaining were intubated with standard polyurethane ETTs (control group).

Presence of colonization was determined by taking biopsies during autopsy. A total of 12 biopsies of $50 \mathrm{mg}$ each were collected from various sites including the five lung lobes, five lobar bronchi, 2 centimeters superior to the carina and one from the trachea at approximately the midpoint of the ETT. Extensive colonization was found in the lower respiratory tract $(\mathrm{p}<.01)$ of the sheep who were intubated with standard ETTs as compared to those in the control group. Although the colonization was most abundant in the lower respiratory tract, it was also present throughout the breathing circuit of the ventilator tubing $(\mathrm{p}=0.003)$ of the control group sample.

The study did have several limitations, including the small sample size of eight participants. Another limitation of the study was that the results were presented in 
difficult to comprehend format (ex: $5.0 \times 105-4.5 \times 108)$. Presenting results/data in this type of format limits the audience that can utilize and interpret the results. In order to understand and utilize the data, readers need to spend more time than expected to find supportive data for their own use.

This study was critically appraised using the CASP tool (Appendix B-2). The study, a randomized controlled trial, addressed the question of whether or not silvercoated ETTs could effectively prevent bacterial colonization of the respiratory tubing and lower respiratory tract. All subjects were similar at the start of the study and accounted for in the results. Unfortunately, it is not clear if all experimental interventions were consistent between the control group and intervention group. Additionally, there were no specifics reporting how the health workers were blinded during treatment/interventions. No treatment effect was reported. Results of the study were similar to results of human studies. However, it is not clear whether or not the results from this study can be applied to human studies. It is unclear if all important outcomes were considered because subjects were euthanized following the study. Euthanization prevented subjects from fully developing VAP. It is unclear if the benefits outweigh the costs/harm caused by this study. Euthanization and animal studies is an ethical question that can only be answered on an individual basis.

The study conducted by Rello et al. (2006; Appendix A-3) was a single blind randomized controlled trial that focused on whether or not reducing bacterial airway colonization with silver-lined ETTs was effective. The study was conducted at four hospitals. One hospital was in the United States and three were in Spain. In order to qualify for the study, participants had to be at least 18 years old, intubated for a minimum 
of 24 hours and be a patient in the intensive care unit (ICU). One hundred fifty-five were screened for the study but only 121 were entered in the study. The 34 that were not entered in the study were either intubated for less than 24 hours or not intubated at all. The intervention group (silver-coated ETTs) consisted of 61 participants and the control group (standard ETTs) consisted of 60 participants. The mean age was 64.6.

The authors identified significant patient risk factors that increased the likelihood of participants developing VAP including previous intubations, recent surgery, trauma patients, use of muscle relaxants (paralytics), continuous sedation, smoking coma, and alcohol abuse. Nineteen participants from the intervention group and 28 from the control group had at least one of these risk factors. Additional risk factors identified in study included enteral nutrition, parenteral nutrition and antibiotic exposure within the previous 14 days. Of the 61 participants in the intervention group, 42 received enteral nutrition, 12 received parenteral nutrition and 32 had received antibiotics within the previous 14 days. Of the 60 participants in the control group, 45 received enteral nutrition, 8 received parenteral nutrition and 30 had received antibiotics within the previous 14 days.

The authors concluded that the silver-coated ETT was effective at reducing bacteria in tracheal aspirates and increasing the time it takes for the inter-lumen of the ETT to become colonized with bacteria. The most significant finding was delayed interlumen colonization of the silver-coated ETTs ( $\mathrm{p}$ 0.02) compared to the standard ETTs (3.2 days for silver ETTs vs 1.8 days for standard ETTs).

Limitations of the study included lack of "blinding" the ICU staff. The ICU staff knew which patients had silver-coated ETTs and which had standard ETTs. This provides a potential for bias and could have impacted how they provided oral care, 
suctioning, etc. Additionally, the infection control process was not standardized between the four hospitals. Lack of standardization could have a significant impact on outcomes/results.

This study was critically appraised using the CASP tool (Appendix B-3). This single-blind study addressed whether a silver-coated ETT could feasibly and safely reduce bacterial colonization of the lungs and tracheal aspirates. All participants who entered the study were accounted for and all relevant clinical outcomes were reported. It is not clear if the control group and intervention group were similar at the start of the trial because only baseline characteristics and demographics were provided. Unfortunately, healthcare workers were not blinded during treatments or data collection and treatment standards varied amongst the four facilities. No treatment effect was reported. It is unclear if the results of this trial could be applied to similar studies due to the lack of standardization among the four facilities (potential for bias). The benefits of the Rello et al. study outweigh the risks/costs. No adverse outcomes were reported.

The NASCENT study conducted by Kollef et al. (2008, Appendix A-4) was a prospective, randomized, single-blind study. The study was conducted between $2002-$ 2006 at 54 medical centers throughout North America. There were 9,417 patients screened for the study and of those, 2,003 were expected to require mechanical ventilation for at least 24 hours. Ultimately, the study involved 1,509 intubated participants. Of those, $n=766$ were intubated with the silver-coated ETT (intervention group) and $n=743$ were intubated with the standard ETT (control group).

Significant risk factors identified prior to the study were smoking, immunodeficiency and Chronic Obstructive Pulmonary Disease (COPD). The number of 
study participants who smoked was 234 . Of the 234 smokers, 121 were intubated with the silver-coated ETT (intervention group) and 113 were intubated with the standard ETT (control group). Of the 370 immune-deficient participants in the study, 184 were intubated with the silver-coated ETT (intervention group) and 186 were intubated with the standard ETT (control group). The number of participants who had COPD was 211. Of the 211 with COPD, 89 were intubated with the silver-coated ETT (intervention group) and 122 were intubated with the standard ETT (control group).

Results of the study (microbiologically confirmed cases of VAP) were a $4.8 \%$ incidence of VAP for the participants intubated with the silver-coated ETT $(n=37)$ and a $7.5 \%$ incidence of VAP for participants intubated with the standard ETT $(n=56)$. These findings had a $95 \%$ confidence rating. The findings suggest a $35.9 \%$ relative risk reduction in the development of VAP for participants intubated with silver-coated ETTs compared to the standard ETTs when intubated for a minimum of 24 hours. Participants with silver-coated ETTs were found to have a substantial reduction in microbiologically confirmed cases of VAP compared to the control group.

An additional finding was a delayed onset of VAP for participants intubated with the silver-coated ETT compared to the standard ETT. After 10 days on intubation, only 27/766 (intervention group) had developed VAP while 50/743 (control group) had already been diagnosed with VAP $(\mathrm{P}=0.005)$.

One of the limitations of this study was that it was limited to patients who could consent for themselves. This precludes a large amount of potential participants who required intubation such as patients in respiratory distress who require emergent intubation or patients who have altered mental status and can't self-consent. These 
patients are highly susceptible to the development of VAP and would have been valuable to include in the study.

This study was critically appraised using the CASP tool (Appendix B-4). The prospective, randomized, single-blind study clearly focused on whether or not a silvercoated ETT would reduce the incidence of microbiologically confirmed VAP. All clinically important outcomes from the study were reported including VAP diagnosis and onset of VAP. Participants in the study were similar at the start of the trial, treatments throughout the trial were consistent, and all were accounted for in the results. Study personnel were blinded to control/intervention group. The treatment effect was a $35.9 \%$ relative risk reduction in incidence of VAP. Results from the Kollef et al. study can be applied to the local population. The benefits outweigh the harms/costs as no adverse outcomes were reported.

The study conducted by Afessa et al. (2010; Appendix A-5) was a retrospective cohort analysis of patients from the NASCENT trial who had developed VAP. Afessa et al. applied a stepwise multivariate logistic regression on the patients from the NASCENT study $(\mathrm{N}=93)$ that developed VAP to determine whether or not there was a reduced mortality rate when a silver-coated ETT was used instead of the standard ETT.

Of the 93 patients, 37 were intubated with a silver-coated ETT (intervention group) and 56 were intubated with the standard ETT (control group). The mean age of the intervention group was 59.8. The mean age of the control group was 63.3. There were no significant demographic differences between the two groups.

Significant patient risk factors identified by the authors included COPD, immunodeficiency, emergent surgery/trauma, inappropriate antibiotic administration, and 
coma. The intervention group contained five COPD patients, eight immunodeficient patients, and three that required emergent surgery or were involved in a trauma. The control group contained seven COPD patients, nine who were immunodeficient, six that required emergent surgery or were involved in a trauma, nine that had received inappropriate antibiotics and one in a coma.

Results from the retrospective cohort analysis found a mortality rate of $14 \%$ for patients in the intervention group that developed VAP $(n=5)$. The mortality rate for patients in the control group that developed VAP was 36\% $(n=20)(p=0.03)($ CI 95\%). The authors concluded that the only variable that altered mortality rate was whether patients were in the intervention group (silver-coated ETT) or the control group (standard ETT).

Another significant finding was a reduction in the development of multidrug resistant bacteria for patients in the intervention group as compared to those in the control group. Of the 37 patients in the intervention group, 13 were diagnosed with bacterial infections that were considered multidrug resistant (approximately 35\%). Of the 56 patients in the control group, $25(45 \%)$ were diagnosed with bacterial infections that were considered multidrug resistant. There was a $29 \%$ reduction in multidrug resistant bacterial infections found in patients intubated with silver-coated ETTs $(p=0.48)$.

The study had two major limitations. Foremost was the limited sample size (N=93). A larger sample size would have strengthened the findings. The second limitation was that the study was a retrospective study of the NASCENT study. Retrospective studies do not prove a direct cause and effect relationship. 
This study was critically appraised using the CASP tool (Appendix B-5). This retrospective cohort analysis of the randomized NASCENT trial addressed whether or not there was an association between silver-coated ETTs and reduced mortality for patients who developed VAP. No significant differences in demographics or risk factors between the control group and the intervention group were reported prior to the study. Study personnel were blinded to the control/intervention groups and followed antibiotic guidelines for administration protocols. Unfortunately, it is not clear what other VAP reduction strategies, such as ventilation strategies, VAP bundles and/or medications were implemented during the study. No treatment effect was reported. However, group designation was found to be a predictor of mortality with a $95 \%$ confidence interval.

All study participants were accounted for in the results. The results of the study were consistent with similar studies throughout this systematic review. It is unclear if all pertinent outcomes were reported during this study. The authors cite a limitation of the inability to prove "cause and effect" between silver-coated ETTs leading to a reduction in patient mortality rates. The benefits of this study $(60 \%$ reduction in mortality rate for the intervention group) outweigh the harms/costs.

A cross study analysis was completed with the CASE worksheets (Appendix C and D). The cross study analysis looks across all studies to determine if there are similarities and/or differences in the findings of each study. All five studies included in this systematic review provided summaries that were specific to the scope of this review. Nearly all, with the exception of the Rello et al., offered transparency to the reader. All studies provided appropriately cited recommendations but unfortunately, the recommendations were dated. Two studies included in this systematic review were 
completed on or prior to 2006. The most current studies were authored by Afessa et al. (2010), Kollef et al. (2008), and Berra et al (2008). The summaries of all studies were unbiased. The most significant study and results included in this systematic review are from Kollef et al. (2008). Based on the large sample size and scope of the study, the results and summary provide detailed data that allows the reader to gauge the accuracy of the intervention (silver-coated ETT) with less potential for bias.

The most significant finding across the studies was a reduction in VAP rates for the intervention group. Each study reported that the intervention group had either fewer patients diagnosed with VAP, a reduction in colonization throughout the ETT/breathing circuit/lungs, or a reduction in mortality rates for patients who were diagnosed with VAP. Next, summary and conclusions will be presented. 


\section{Summary and Conclusions}

A systematic review was conducted to determine whether silver-coated ETTs were effective at reducing the incidence of VAP when compared to standard ETTs. A comprehensive literature review was conducted using CINAHL, OVID and PubMed. The literature review focused on ventilator-associated pneumonia, ETTs, silversulfadiazine, and VAP. An abundance of literature was found pertaining to VAP and silver-sulfadiazine individually. However, information linking these topics was limited.

After identifying inclusion and exclusion criteria and using the PRISMA

flowchart, five studies were identified. Data collection tables that identified key variables for each of the individual studies were developed and completed. Then, each study was critically appraised using the The Critical Appraisal Skills Programme (CASP) tool. The Critical Appraisal Skills Programme helped determine if the study was valid, what the results meant and if the results were useful. It was also used to screen the studies in a structured manner so that a determination could be made regarding the validity of the data reported within the study.

Following the critical appraisal, a cross-study analysis was completed with the CASE worksheet. The Critical Appraisal Skills Programme was used to gauge transparency of the study, understand the scope of the study, identify any potential bias, and review the author's recommendations following the results. Findings across the five studies were also compared and contrasted.

After extensively reviewing and appraising the studies, Kollef et al. (2008). Afessa et al. (2010) and Rello et al. (2006) provided the most relevant data for this systematic review since these studies used human subjects and had larger sample sizes. 
Kollef et al. and Rello et al. conducted their studies at multiple sites. One methodological problem identified from the Kollef et al. and Afessa et al. studies was a lack of documentation regarding patient care standards. Key components of patient treatment including frequency of antibiotics, VAP bundles, and additional preventative strategies were not clear.

Both Berra et al. studies (2004 and 2008) provided valuable data for this systematic review; however, these were animal studies. The results were consistent with human studies. While the results are essential to this systematic review, the results of animal studies do not have the same significance to researchers as human studies. One methodological limitation to the Berra et al. studies was the absence of treatment effect and another limitation was a question of benefit from the study. The question of benefit stems from the fact that all subjects involved in the Berra et al. studies were euthanized at the conclusion of the study.

All studies reported a reduction or absence of bacteria within the breathing circuit, ETT or lungs of the subjects from the intervention group as compared to the control group. These findings were consistent across all studies. One landmark study, Kollef et al. (2008) not only found a 35.9\% relative risk reduction in microbiologically confirmed cases of VAP for the intervention group, but also reported that it took significantly longer for the intervention group to develop VAP $(\mathrm{p}<.005)$. In addition to reduced colonization, Afessa et al. (2010) reported a reduction in mortality rate for patients who were in the intervention group $n=5(14 \%)$ that developed VAP compared to the control group $n=20$ (36\%). 
There were several limitations throughout this systematic review. One of the limitations was the number of studies available that met the inclusion criteria. Only five were identified as appropriate based on the inclusion criteria and thus additional research is needed. Another limitation was the age of some of the studies, including Berra et al. performed in 2004 and Berra et al. from 2008. Although the study was not current, the results of the study were consistent with more recent studies. One additional limitation was the subjects in two of the studies were not human. Berra et al. (2004) and Berra et al. (2008) studies were conducted on Dorset sheep.

In summary, the results of the studies included in this systematic review concluded that silver-coated ETTs effectively reduce the incidence of VAP. Findings were consistent across the studies.

Next, the recommendations and implications for advanced practice nursing will be discussed. 


\section{Recommendations and Implications for Advanced Nursing Practice}

Ventilator-associated pneumonia is an expensive and dangerous complication of mechanical ventilation. Ventilator-associated pneumonia prevention is a national patient safety standard. When patients develop VAP, they require longer periods of intubation and mechanical ventilation. Endotracheal tubes increase the risk of developing pneumonia by suppressing innate protective airway reflexes (Miller et al., 2014). A microbiologically confirmed case of VAP also prolongs hospital stays, increases the cost of the hospitalization, requires increased hospital services and increases the risk of death.

As care-providers for acutely ill patients throughout the operating rooms, intensive care units and emergency rooms, Certified Registered Nurse Anesthetists (CRNAs) must advocate for additional strategies to prevent VAP for patients that remain intubated following procedures. One of those strategies is using products impregnated with silver. Silver-coated ETTs can reduce the bacterial colonization of ETTs, breathing circuits and a patient's lungs.

Education and training by CRNAs should focus on identifying patients preoperatively that are likely to need prolonged mechanical ventilation. These patients are at high-risk for developing VAP. While evidence-based interventions such as elevation of the head of the bed, prophylactic stress ulcer medication, oral care with chlorhexidine, and prophylactic deep vein thrombus injections remain the most common interventions used to reduce the development of VAP in the ICU, CRNAs can intervene even earlier by identifying these patients and consulting with the surgeon to determine if post-operative intubation is likely. 
Certified Registered Nurse Anesthetists are in a key position to advocate on patients' behalf for the use of silver-coated ETTs as a proactive approach to reduce the risk of developing VAP for those who are likely to remain intubated for greater than 24 hours. By educating caregivers about the benefits of silver-coated ETTs for patients requiring prolonged intubation following surgery, CRNAs can help improve patient outcomes, reduce costs associated with hospital admissions, and reduce the risk of death in patients who develop VAP.

Certified Registered Nurse Anesthetists should be involved with policy development related to VAP, silver-coated ETTs and prevention strategies. As CRNAs, our impact on patient care should not be limited to the OR. As master's educated providers of care, CRNAs are trained to review and interpret research. Interpreting and validating study results with the assistance of tools such as PRISMA, CASP, and CASE are foundational to policy development, which provide the framework for improvements to patient care. Input regarding evidence-based treatment interventions and improving patient outcomes are needed. The CRNA can also advocate for policy at the national level via participation in professional organizations

Further research is needed to confirm the results reported in this systematic review. Research should focus on patient outcomes following intubation with silvercoated ETTs, any adverse outcomes, and financial considerations that may occur as a result of implementing a policy related to intubations with silver-coated ETTs for patients requiring prolonged intubation following surgery. 
Certified Registered Nurse Anesthetists are in a unique position to advocate for patients, educate staff about treatment strategies, and develop policy based on evidencebased practice. Due to the expanding role of CRNAs across the healthcare spectrum, it is critical CRNAs remain current with medical research, medical innovation, and treatment strategies. 


\section{References}

Afessa, B., Shorr, A.F., Anzueto, A.R., Craven, D.E., Schinner, R., \& Kollef, M.H. (2010, May). Association between a silver-coated endotracheal tube and reduced mortality in patients with ventilator-associated pneumonia. Chest, 137(5), 10151021. http://doi: 10.1378/chest.09-0391

Berra, L., De Marchi, L., Yu, Z. X., Laquerriere, P., Baccarelli, A., \& Kolobow, T. (2004). Endotracheal tubes coated with antiseptics decrease bacterial colonization of the ventilator circuits, lungs, and endotracheal tube. Anesthesiology: The Journal of the American Society of Anesthesiologists, 100(6), 1446-1456.

Berra, L., Kolobow, T., Laquerriere, P., Pitts, B., Bramati, S., Pohlmann, J., ... \& Baccarelli, A. (2008). Internally coated endotracheal tubes with silver sulfadiazine in polyurethane to prevent bacterial colonization: a clinical trial. Intensive Care Medicine, 34(6), 1030.

Bigham, M. T., Amato, R., Bondurrant, P., Fridriksson, J., Krawczeski, C. D., Raake, J., ... \& Brilli, R. J. (2009). Ventilator-associated pneumonia in the pediatric intensive care unit: characterizing the problem and implementing a sustainable solution. The Journal of Pediatrics, 154(4), 582-587.

Brandt, O., Mildner, M., Egger, A. E., Groessl, M., Rix, U., Posch, M., ... \& Stingl, G. (2012). Nanoscalic silver possesses broad-spectrum antimicrobial activities and exhibits fewer toxicological side effects than silver sulfadiazine. Nanomedicine: Nanotechnology, Biology and Medicine, 8(4), 478-488.

Critical Appraisal Skills Programme (CASP). (n.d.). Retrieved November 1, 2017, from http://www.casp-uk.net/ 
Durán, N., Durán, M., de Jesus, M. B., Seabra, A. B., Fávaro, W. J., \& Nakazato, G. (2016). Silver nanoparticles: A new view on mechanistic aspects on antimicrobial activity. Nanomedicine: Nanotechnology, Biology and Medicine, 12(3), 789-799.

Fernandez, J.F., Levine, S.M., \& Restrepo, M.I. (2012, July). Technologic advances in endotracheal tubes for prevention of ventilator-associated pneumonia. Chest, 142(1), 231-238. http://doi:10.1378/chest.11-2420.

Foster, M. J., \& Shurtz, S. (2013). Making the Critical Appraisal for Summaries of Evidence (CASE) for evidence-based medicine (EBM): critical appraisal of summaries of evidence. Journal of the Medical Library Association: JMLA, 101(3), 192.

Franci, G., Falanga, A., Galdiero, S., Palomba, L., Rai, M., Morelli, G., \& Galdiero, M. (2015). Silver nanoparticles as potential antibacterial agents. Molecules, 20(5), 8856-8874.

Ge, L., Li, Q., Wang, M., Ouyang, J., Li, X., \& Xing, M. M. (2014). Nanosilver particles in medical applications: synthesis, performance, and toxicity. International Journal of Nanomedicine, 9, 2399.

Haas, C.F., Eakin, R.M., Konkle, M.A., \& Blank, R. (2014). Endotracheal tubes: Old and new. Respiratory Care, 59(6), 933-955. http://doi:10.4187/respcare.02868

Hunter, J. D. (2012). Ventilator associated pneumonia. BMJ, 344(e3325), e3325.

Institute for Healthcare Improvement. (IHI). (n.d.). Retrieved August 15, 2016 from http://www.ihi.org/ 
Kalil, A. C., Metersky, M. L., Klompas, M., Muscedere, J., Sweeney, D. A., Palmer, L. B., ... \& El Solh, A. A. (2016). Management of adults with hospital-acquired and ventilator-associated pneumonia: 2016 Clinical Practice Guidelines by the Infectious Diseases Society of America and the American Thoracic Society. Clinical Infectious Diseases, 63(5), 61-111.

Kalanuria, A. A., Zai, W., \& Mirski, M. (2014). Ventilator-associated pneumonia in the ICU. Critical care, 18(2), 208.

Kollef, M.H., Afessa, B., Anzueto, A., Veremakis, C., Kerr, K.M., Margolis, B.D., ... Schinner, R. (2008). Silver-coated endotracheal tubes and incidence of ventilator- associated pneumonia: The Nascent randomized trial. The Journal of the American Medical Association, 300(7), 805-813.

http://doi:10.1001/jama.300.7.805

Marx, D. E., \& Barillo, D. J. (2014). Silver in medicine: the basic science. Burns, 40, S9S18.

Mietto, C., Pinciroli, R., Patel, N., \& Berra, L. (2013). Ventilator associated pneumonia: Evolving definitions and preventive strategies. Respiratory Care, 58(6), 9901007. http://doi:10.4187/respcare.02380

Miller, R. D., Eriksson, L. I., Fleisher, L. A., Wiener-Kronish, J. P., Cohen, N. H., \& Young, W.L. (2014). Miller's Anesthesia. Philadelphia, PA. Elsevier Health Sciences.

Moher, D., Liberati, A., Tetzlaff, J., \& Altman, D. G. (2009). Preferred reporting items for systematic reviews and meta-analyses: the PRISMA statement. Annals of Internal Medicine, 151(4), 264-269. 
Moher, D., Shamseer, L., Clarke, M., Ghersi, D., Liberati, A., Petticrew, M., ... \& Stewart, L. A. (2015). Preferred reporting items for systematic review and metaanalysis protocols (PRISMA-P) 2015 statement. Systematic reviews, 4(1), 1. http://doi.org/10.1186/2046-4053-4-1

Monteiro, D. R., Gorup, L. F., Takamiya, A. S., Ruvollo-Filho, A. C., de Camargo, E. R., \& Barbosa, D. B. (2009). The growing importance of materials that prevent microbial adhesion: antimicrobial effect of medical devices containing silver. International Journal of Antimicrobial Agents, 34(2), 103-110.

Palanisamy, N. K., Ferina, N., Amirulhusni, A. N., Mohd-Zain, Z., Hussaini, J., Ping, L. J., \& Durairaj, R. (2014). Antibiofilm properties of chemically synthesized silver nanoparticles found against Pseudomonas aeruginosa. Journal of Nanobiotechnology, 12(1), 2-7.

Pirrone, M., Pinciroli, R., \& Berra, L. (2016). Microbiome, biofilms, and pneumonia in the ICU. Current opinion in infectious diseases, 29(2), 160-166.

PRISMA. (n.d.). Retrieved June 15, 2016, from http://prisma-statement.org/

Rai, M., Yadav, A., \& Gade, A. (2009). Silver nanoparticles as a new generation of antimicrobials. Biotechnology Advances, 27(1), 76-83.

Rello, J., Kollef, M., Diaz, E., Sandiumenge, A., del Castillo, Y., Corbella, X., \& Zachskorn, R. (2006). Reduced burden of bacterial airway colonization with a novel silver-coated endotracheal tube in a randomized multiple-center feasibility study. Critical Care Medicine, 34(11), 2766-2772.

Resar, R., Pronovost, P., Haraden, C., Simmonds, T., Rainey, T., \& Nolan, T. (2005). Using a bundle approach to improve ventilator care processes and reduce 
ventilator-associated pneumonia. The Joint Commission Journal on Quality and Patient Safety, 31(5), 243-248.

Shorr, A. F., Zilberberg, M. D., \& Kollef, M. (2009). Cost-effectiveness analysis of a silver-coated endotracheal tube to reduce the incidence of ventilator-associated pneumonia. Infection Control \& Hospital Epidemiology, 30(08), 759-763.

Tokmaji, G., Vermeulen, H., Müller, M. C., Kwakman, P. H., Schultz, M. J., \& Zaat, S. A. (2015). Silver-coated endotracheal tubes for prevention of ventilator-associated pneumonia in critically ill patients. The Cochrane Library. http://onlinelibrary.wiley.com/doi/10.1002/14651858.

Wan, G., Ruan, L., Yin, Y., Yang, T., Ge, M., \& Cheng, X. (2016). Effects of silver nanoparticles in combination with antibiotics on the resistant bacteria Acinetobacter baumannii. International journal of nanomedicine, 11, 3789-3800. 
Table A-1.

\section{Appendix A}

Berra, L., De Marchi, L., Yu, Z. X., Laquerriere, P., Baccarelli, A., \& Kolobow, T. (2004). Endotracheal tubes coated with antiseptics decrease bacterial colonization of the ventilator circuits, lungs, and endotracheal tube. Anesthesiology: The Journal of the American Society of Anesthesiologists, 100(6), 1446-1456.

\begin{tabular}{|c|c|c|c|c|c|}
\hline Study Design & Site/Sample & $\begin{array}{l}\text { Patient Risk } \\
\text { Factors Prior to } \\
\text { Intubation }\end{array}$ & $\begin{array}{l}\text { Duration of } \\
\text { Intubation }\end{array}$ & $\begin{array}{l}\text { Outcomes of } \\
\text { Intubation }\end{array}$ & Limitations \\
\hline $\begin{array}{l}\text { Randomized- } \\
\text { controlled } \\
\text { study. } \\
\text { Control group: } \\
\text { n = } 8 \text { with } \\
\text { standard } \\
\text { uncoated ETTs. } \\
\text { Study group: } \\
\text { n = } 8 \text { with silver } \\
\text { coated ETTs }\end{array}$ & $\begin{array}{l}\text { National } \\
\text { Institutes of } \\
\text { Health Animal } \\
\text { Research } \\
\text { Laboratory } \\
\text { (Bethesda, } \\
\text { Maryland). } \\
\text { Subjects were } \\
\mathrm{N}=16 \text { Sheep, } \\
\text { female Dorset } \\
\text { Median body } \\
\text { weight = 30.5kg } \\
\text { (range = 25- } \\
\text { 37kg). } \\
\text { Microscopic } \\
\text { and }\end{array}$ & $\begin{array}{l}\text { No predetermined } \\
\text { risk factors based } \\
\text { on laboratory data } \\
\text { and chest } \\
\text { radiograph } 3 \text { days } \\
\text { prior to the study } \\
\text { Subjects had not } \\
\text { received any } \\
\text { antibiotics for a } \\
\text { minimum of } 4 \\
\text { weeks prior to the } \\
\text { study. }\end{array}$ & $\begin{array}{l}\text { Intubation = } 24 \\
\text { hours with } \\
\text { mechanical } \\
\text { ventilation. } \\
\text { Intubation and } \\
\text { securement of } \\
\text { airway was } \\
\text { completed on first } \\
\text { attempt (without } \\
\text { difficulty) for all } \\
\mathrm{N} 16 \text { subjects. } \\
\text { Respiratory and } \\
\text { hemodynamic } \\
\text { parameters, core } \\
\text { body temperature, } \\
\text { arterial blood gases, } \\
\text { and urinary output }\end{array}$ & $\begin{array}{l}\text { Following the study, } \\
\text { an autopsy was } \\
\text { conducted and } \\
\text { included tissue } \\
\text { samples from the } \\
\text { trachea, larynx, } \\
\text { bronchi, and the } 5 \\
\text { lobes of the lungs. }\end{array}$ & $\begin{array}{l}\text { After } 24 \text { hours of } \\
\text { mechanical } \\
\text { ventilation, subjects } \\
\text { were euthanized. } \\
\text { This prevented the } \\
\text { subjects from } \\
\text { developing } \\
\text { pneumonia (which } \\
\text { likely would have } \\
\text { occurred with } \\
\text { bacterial } \\
\text { colonization within } \\
\text { the lower } \\
\text { respiratory tract). }\end{array}$ \\
\hline
\end{tabular}




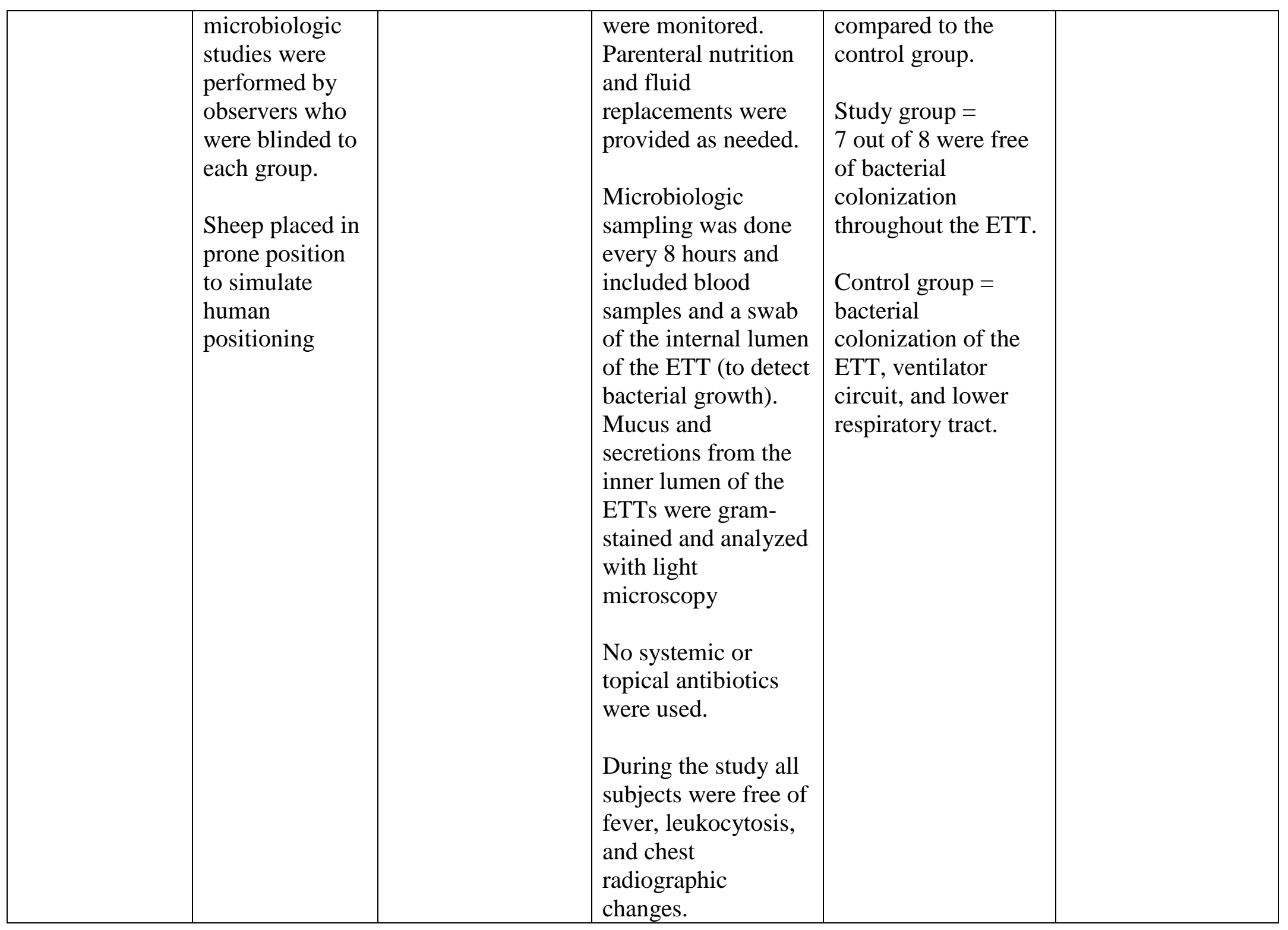


Table A-2.

Berra, L., Kolobow, T., Laquerriere, P., Pitts, B., Bramati, S., Pohlmann, J., ... \& Baccarelli, A. (2008). Internally coated endotracheal tubes with silver sulfadiazine in polyurethane to prevent bacterial colonization: a clinical trial. Intensive Care Medicine, 34(6), 1030.

\begin{tabular}{|c|c|c|c|c|c|}
\hline Study Design & Site/Sample & $\begin{array}{l}\text { Patient Risk Factors } \\
\text { Prior to Intubation }\end{array}$ & $\begin{array}{l}\text { Duration of } \\
\text { Intubation }\end{array}$ & Results & Limitations \\
\hline $\begin{array}{l}\text { Randomized } \\
\text { Controlled Trial } \\
\text { Dorset Sheep } \\
\text { mechanically } \\
\text { ventilated }\end{array}$ & $\begin{array}{l}\text { Laboratory- } \\
\text { National Institute of } \\
\text { Health (Bethesda, } \\
\text { Maryland) } \\
\mathrm{N}=8 \\
\text { Silver coated ETT } \\
(\mathrm{n}=4) \\
\text { Standard ETT } \\
(\mathrm{n}=4)\end{array}$ & $\begin{array}{l}\text { Healthy upon } \\
\text { enrollment based } \\
\text { on clinical findings, } \\
\text { lab values, and } \\
\text { chest radiographs } \\
\text { throughout the } \\
\text { intubation period } \\
\text { Intubation } \\
\text { successful on } 1^{\text {st }} \\
\text { attempt for all } \\
\text { participants }\end{array}$ & 24 hours & $\begin{array}{l}\text { Autopsy-12 biopsy } \\
\text { samples ( } 50 \mathrm{mg} \\
\text { each) } \\
5 \text { ( } 1 \text { from each lung } \\
\text { lobe) } \\
5 \text { (lobar bronchi) } \\
1 \text { ( } 2 \mathrm{~cm} \text { above } \\
\text { carina) } \\
1 \text { (middle of ETT) } \\
\text { Standard ETT- } \\
\text { lower respiratory } \\
\text { tract } \\
\text { (p }<.01) \text { and } \\
\text { ventilator tubing } \\
\text { extensively } \\
\text { colonized (p = } \\
.003) \\
\text { Silver coated ETT- } \\
\text { no colonization }\end{array}$ & $\begin{array}{l}\text { Study limited to } 24 \\
\text { hours } \\
8 \text { subjects } \\
\text { Microscopy and } \\
\text { bacteriology } \\
\text { findings difficult } \\
\text { for the reader to } \\
\text { quantify } \\
\text { (example: } 5.0 \times \\
105-4.5 \times 108)\end{array}$ \\
\hline
\end{tabular}




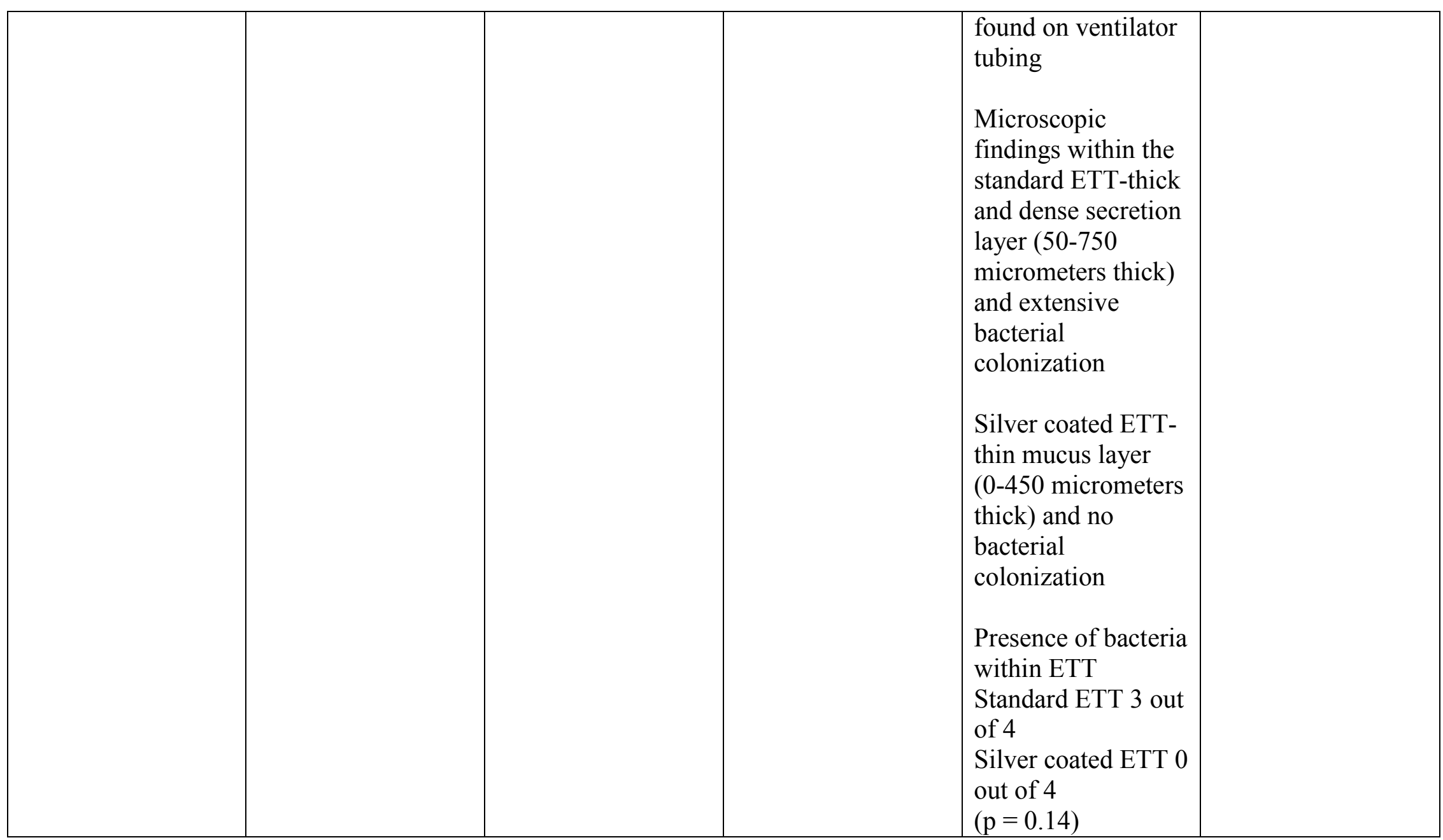

P values calculated using Wilcoxon-Mann-Whitney and Fisher's exact test
fuing
Microscopic
findings within the standard ETT-thick and dense secretion er (50-750 and extensive
bacterial
Silver coated ETT- thin mucus layer (0-450 micrometers thick) and no
bacterial
Presence of bacteria within ETT
Standard ETT 3 ou of 4 out of 4 $(p=0.14)$ 
Table A- 3.

Rello, J., Kollef, M., Diaz, E., Sandiumenge, A., del Castillo, Y., Corbella, X., \& Zachskorn, R. (2006). Reduced burden of bacterial airway colonization with a novel silver-coated endotracheal tube in a randomized multiple-center feasibility study. Critical Care

Medicine, 34(11), 2766-2772.

\begin{tabular}{|c|c|c|c|c|c|}
\hline Study Design & Site/Sample & $\begin{array}{l}\text { Patient risk factors } \\
\text { prior to intubation }\end{array}$ & $\begin{array}{l}\text { Duration of } \\
\text { Intubation }\end{array}$ & Results & Limitations \\
\hline $\begin{array}{l}\text { Randomized } \\
\text { Controlled Trial } \\
\text { utilizing allocation } \\
\text { concealment } \\
\text { Single blind study }\end{array}$ & $\begin{array}{l}\text { ICU patients } 18 \\
\text { years and older } \\
\text { (mean age } 64.6 \text { ) } \\
\mathrm{N}=155 \\
34 \text { excluded (6 not } \\
\text { intubated and } 28 \\
\text { intubated less than } \\
24 \text { hours) } \\
121 \text { intubated for } \\
\text { minimum } 24 \text { hours } \\
61 \text { with silver } \\
\text { coated ETT/60 with } \\
\text { standard ETT }\end{array}$ & $\begin{array}{l}\text { Antibiotic exposure } \\
\text { within past } 14 \text { days } \\
\text { RIC (Respiratory } \\
\text { Infection Control) } \\
\text { Silver ETT=32 } \\
\text { Standard ETT = } 30 \\
\text { Risk factors for } \\
\text { VAP during } \\
\text { previous } 30 \text { days } \\
\text { include previous } \\
\text { intubations, } \\
\text { surgery, trauma, } \\
\text { use of muscle } \\
\text { relaxants, } \\
\text { continuous } \\
\text { sedation, smoking, }\end{array}$ & $\begin{array}{l}\text { Minimum of } 24 \\
\text { hours }\end{array}$ & $\begin{array}{l}\text { Silver device had } \\
\text { delayed microbial } \\
\text { colonization } \\
\text { compared to } \\
\text { standard ETT } \\
\text { (p .02) } \\
\text { Silver ETT had } \\
\text { bacterial burden } \\
\text { found in tracheal } \\
\text { aspirates } \\
\text { Silver tube showed } \\
\text { delayed inter-lumen } \\
\text { colonization } 1.8 \\
\text { days for RIC device } \\
\text { compared to } 3.2\end{array}$ & $\begin{array}{l}\text { No "blinding" of } \\
\text { outcome } \\
\text { assessment } \\
\text { (potential for } \\
\text { detection bias) } \\
\text { No blinding of } \\
\text { participants and } \\
\text { personnel (potential } \\
\text { for performance } \\
\text { bias) } \\
\text { ICU staff may have } \\
\text { bias due to inability } \\
\text { to "blind" them as } \\
\text { the ETTs are }\end{array}$ \\
\hline
\end{tabular}




\begin{tabular}{|c|c|c|c|c|}
\hline & $\begin{array}{l}4 \text { Hospitals- } 1 \text { in the } \\
\text { United States } \\
(\mathrm{n}=56) \text { and } 3 \text { in } \\
\text { Spain }(\mathrm{n}=99)\end{array}$ & $\begin{array}{l}\text { coma, alcohol } \\
\text { abuse }(\mathrm{p} .09) \\
\text { Silver ETT }=19 \\
\text { Standard ETT }=28 \\
\text { Enteral nutrition } \\
\text { Silver ETT }=42 \\
\text { Standard ETT }=45 \\
\text { Parenteral nutrition } \\
\text { Silver ETT }=12 \\
\text { Standard ETT }=8\end{array}$ & $\begin{array}{l}\text { days for standard } \\
\text { ETT } \\
(\text { p .02) }\end{array}$ & $\begin{array}{l}\text { different in } \\
\text { appearance }\end{array}$ \\
\hline
\end{tabular}


Table A-4.

Kollef, M. H., Afessa, B., Anzueto, A., Veremakis, C., Kerr, K. M., Margolis, B. D., ... \& Restrepo, M. I. (2008). Silver-coated endotracheal tubes and incidence of ventilator-associated pneumonia: the NASCENT randomized trial. JAMA, 300(7), 805-813.

\begin{tabular}{|c|c|c|c|c|c|}
\hline Study Design & Site/Sample & $\begin{array}{l}\text { Risk factors prior to } \\
\text { intubation }\end{array}$ & $\begin{array}{l}\text { Duration of } \\
\text { Intubation }\end{array}$ & Results & Limitations \\
\hline $\begin{array}{l}\text { A prospective, } \\
\text { randomized, } \\
\text { single-blind } \\
\text { controlled } \\
\text { study. } \\
\text { Each site was } \\
\text { given } \\
\text { numbered } \\
\text { envelopes that } \\
\text { contained a } \\
\text { randomization } \\
\text { card for each } \\
\text { study } \\
\text { participant. } \\
\\
\text { Microbiology } \\
\text { lab personnel } \\
\text { and study } \\
\text { investigators } \\
\text { were blinded }\end{array}$ & $\begin{array}{c}\text { Fifty-four medical } \\
\text { centers throughout } \\
\text { North America } \\
\text { between 2002- } \\
2006 . \\
9417 \text { patients were } \\
\text { screened for the } \\
\text { study. } \\
\mathrm{N}=2003 \text { patients } \\
\text { that were expected } \\
\text { to require } \\
\text { mechanical } \\
\text { ventilation for } \\
\text { greater than } 24 \\
\text { hours were } \\
\text { identified and } \\
\text { randomized for the } \\
\text { study. }\end{array}$ & $\begin{array}{l}\text { Smoker }(\mathrm{n}=121 \text { with } \\
\text { silver-coated ETT; } \\
\mathrm{n}=113 \text { with standard } \\
\text { ETT). } \\
\text { Immunodeficiency ( } \mathrm{n}= \\
184 \text { patients who had the } \\
\text { silver-coated ETT and } \\
\mathrm{n}=186 \text { who had the } \\
\text { standard ETT). } \\
\text { COPD ( } \mathrm{n}=89 \text { patients } \\
\text { that had the silver-coated } \\
\text { ETT and } \mathrm{n}=122 \text { patients } \\
\text { that had the standard } \\
\text { ETT) }\end{array}$ & $>$ n 24 hours. & $\begin{array}{l}\text { With a } 95 \% \text { confidence } \\
\text { rating, } \mathrm{n}=37 \text { patients } \\
\text { with the silver-coated } \\
\text { ETT were diagnosed with } \\
\text { microbiologically } \\
\text { confirmed cases of VAP } \\
\text { (4.8\%). } \\
\mathrm{n}=56 \text { patients with } \\
\text { standard ETT were } \\
\text { diagnosed with } \\
\text { microbiologically } \\
\text { confirmed cases of VAP } \\
\text { (7.5\%). } \\
\text { Findings suggest a 35.9\% } \\
\text { relative risk reduction in } \\
\text { the development of VAP } \\
\text { for patients intubated } \\
\text { greater than } 24 \text { hours. }\end{array}$ & $\begin{array}{l}\text { Only patients able } \\
\text { to consent were } \\
\text { included in the } \\
\text { study. This } \\
\text { prevented patients } \\
\text { who required } \\
\text { emergent } \\
\text { intubations, those } \\
\text { with a change in } \\
\text { mental status, and } \\
\text { other high risk } \\
\text { patients from } \\
\text { participating in the } \\
\text { study. These } \\
\text { patients are highly } \\
\text { susceptible to } \\
\text { developing VAP. }\end{array}$ \\
\hline
\end{tabular}




\begin{tabular}{|c|c|c|}
\hline $\begin{array}{c}\text { to group } \\
\text { data/specifics. }\end{array}$ & $\begin{array}{c}\mathrm{n}=766 \text { with } \\
\text { silver-coated ETT. } \\
\text { n=743 with } \\
\text { standard ETT. } \\
\text { Human subjects } \\
\text { were used for this } \\
\text { study. }\end{array}$ & $\begin{array}{l}\text { Patients with silver-coated } \\
\text { ETT had substantial } \\
\text { reduction in diagnosed } \\
\text { cases of VAP. } \\
\text { Patients with silver-coated } \\
\text { ETT took longer to } \\
\text { develop VAP (10 days) } \\
n=27 / 766 \text { than patients } \\
\text { who had the standard ETT } \\
n=50 / 743(\mathrm{P}=0.005)\end{array}$ \\
\hline
\end{tabular}


Table A-5.

Afessa, B., Shorr, A. F., Anzueto, A. R., Craven, D. E., Schinner, R., \& Kollef, M. H. (2010). Association between a silver-coated endotracheal tube and reduced mortality in patients with ventilator-associated pneumonia. CHEST Journal, 137(5), $1015-1021$.

\begin{tabular}{|c|c|c|c|c|c|}
\hline Study Design & Site/Sample & $\begin{array}{l}\text { Patient risk factors prior to } \\
\text { intubation }\end{array}$ & $\begin{array}{l}\text { Duration of } \\
\text { Intubation }\end{array}$ & Results & Limitations \\
\hline $\begin{array}{l}\text { Retrospective } \\
\text { cohort } \\
\text { analysis for } \\
\text { patients who } \\
\text { developed } \\
\text { VAP in } \\
\text { NASCENT } \\
\text { study } \\
\text { (N 93) } \\
\text { Stepwise } \\
\text { multivariate } \\
\text { logistic } \\
\text { regression }\end{array}$ & $\begin{array}{l}\text { N } 93 \text { with } \\
\text { microbiologically } \\
\text { confirmed VAP } \\
\text { Silver ETT n = } \\
37 \\
\text { Mean age } 59.8 \\
\text { Standard ETT } \\
\text { n=56 } \\
\text { Mean age } 63.3 \\
\text { No significant } \\
\text { demographic } \\
\text { differences } \\
\text { between groups }\end{array}$ & $\begin{array}{l}\text { Silver ETT } \\
\text { COPD }=5 \\
\text { Immunodeficiency }=8 \\
\text { Emergency surgery/trauma }=3 \\
\text { Inappropriate antibiotics }=6 \\
\text { Coma = } 0 \\
\text { Standard ETT } \\
\text { COPD = 7 } \\
\text { Immunodeficiency = } \\
\text { Emergency surgery/trauma }=6 \\
\text { Inappropriate antibiotics }=9 \\
\text { Coma = } 1\end{array}$ & $\begin{array}{l}\text { Greater than } \\
24 \text { hours }\end{array}$ & $\begin{array}{l}\text { Mortality rate for } \\
\text { VAP patients } \\
\text { with silver ETT } \\
14 \%(\mathrm{n}=5) \\
\text { Mortality rate for } \\
\text { VAP with } \\
\text { standard ETT } \\
36 \%(\mathrm{n}=20) \\
\mathrm{P}=0.03 \\
\text { Only variable } \\
\text { that altered } \\
\text { mortality rate } \\
\text { was treatment } \\
\text { group (silver } \\
\text { ETT vs standard } \\
\text { ETT) } 95 \% \text { CI }\end{array}$ & $\begin{array}{l}\text { Retrospective studies } \\
\text { do not prove a cause } \\
\text { and effect relationship } \\
\text { (silver vs standard } \\
\text { ETT) } \\
\text { Small sample size (N } \\
\text { 93) }\end{array}$ \\
\hline
\end{tabular}




\begin{tabular}{|l|l|l|l|}
\hline & & & $\begin{array}{l}\text { Silver ETT }=13 \\
\text { developed } \\
\text { potentially } \\
\text { multidrug } \\
\text { resistant bacteria } \\
\text { Control group }= \\
25 \text { developed } \\
\text { potentially } \\
\text { multidrug } \\
\text { resistant bacteria } \\
\text { (P=0.48) }\end{array}$ \\
& \\
& \\
& \\
\hline
\end{tabular}




\section{Appendix B}

\section{Critical Appraisal Skills Programme (CASP) Tables}

Table B-1.

Berra, L., De Marchi, L., Yu, Z. X., Laquerriere, P., Baccarelli, A., \& Kolobow, T. (2004). Endotracheal tubes coated with antiseptics decrease bacterial colonization of the ventilator circuits, lungs, and endotracheal tube. Anesthesiology: The Journal of the American Society of Anesthesiologists, 100(6), 1446-1456.

\begin{tabular}{|l|l|l|l|}
\hline \multicolumn{1}{|c|}{ Question } & Yes & Can't & No \\
1) Did the review address a clearly focused question? & $\mathbf{X}$ & & \\
Yes. The study focused on bacterial colonization of the & & & \\
lungs, ETT, and ventilator circuit when an ETT coated with \\
silver-sulfadiazine was used.
\end{tabular}




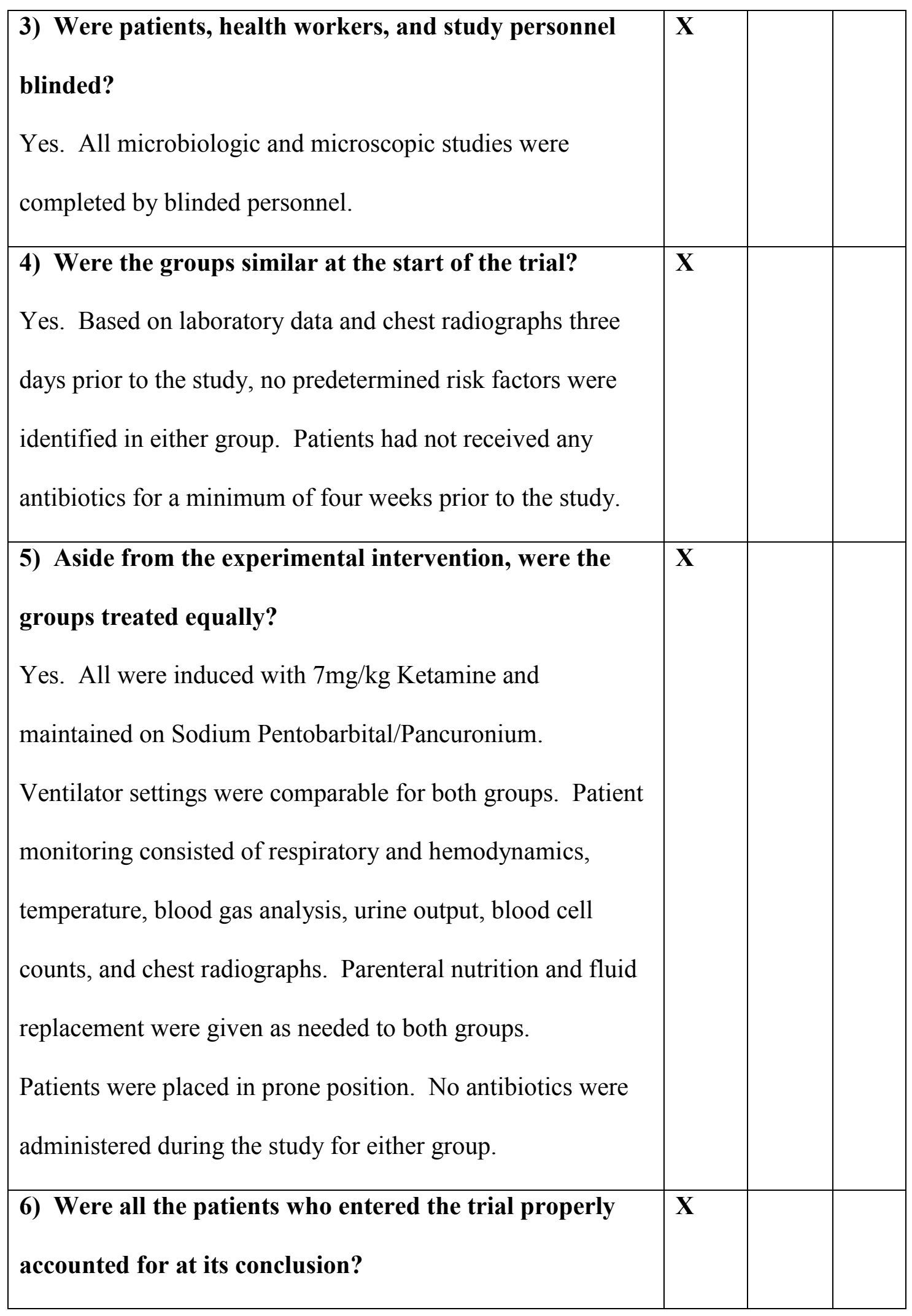




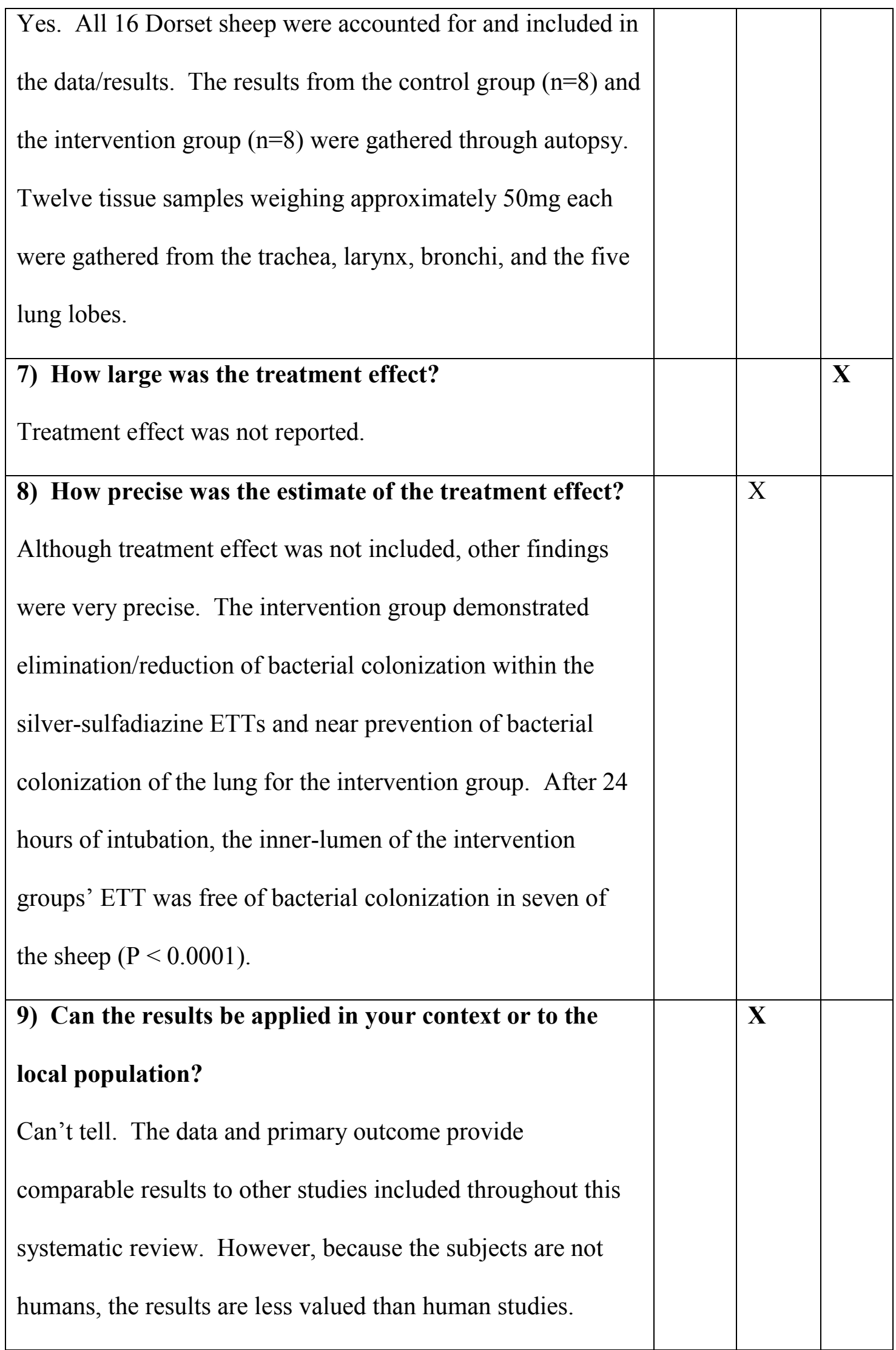




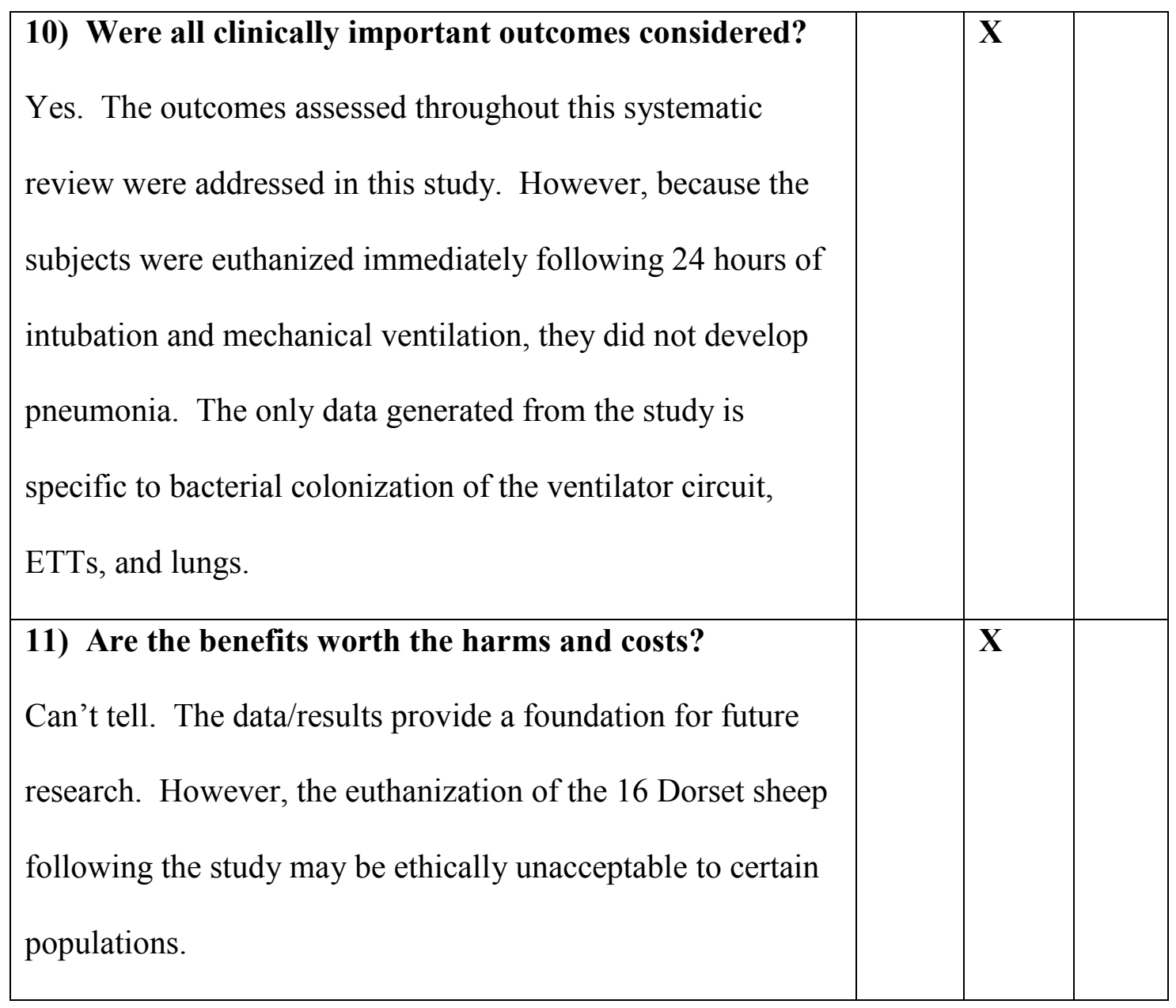


Table B-2.

Berra, L., Kolobow, T., Laquerriere, P., Pitts, B., Bramati, S., Pohlmann, J., ... \&

Baccarelli, A. (2008). Internally coated endotracheal tubes with silver sulfadiazine in polyurethane to prevent bacterial colonization: a clinical trial. Intensive Care Medicine, 34(6), 1030.

\begin{tabular}{|l|l|l|l|}
\hline \multicolumn{1}{|c|}{ Question } & Yes & Can't & No \\
1) Did the review address a clearly focused question? & X & & \\
Yes. The review addressed whether or not silver-coated & & & \\
ETTs could effectively prevent bacterial colonization of the \\
respiratory tubing and lower respiratory tract.
\end{tabular}




\begin{tabular}{|c|c|c|c|}
\hline $\begin{array}{l}\text { 4) Were the groups similar at the start of the trial? } \\
\text { Yes. All subjects were healthy upon enrollment in the study } \\
\text { based on lab values, clinical findings, and chest X-rays. } \\
\text { During the 24-hour study, no fevers, purulent drainage from } \\
\text { the ETTs, abnormalities on chest X-ray, or leukocytosis was } \\
\text { found. }\end{array}$ & $\mathbf{X}$ & & \\
\hline $\begin{array}{l}\text { 5) Aside from the experimental intervention, were the } \\
\text { groups treated equally? } \\
\text { Can't tell. The trail does not provide specifics regarding } \\
\text { standardization of treatment throughout the } 24 \text {-hour study. } \\
\text { One documented detail of significance was that all subjects } \\
\text { were successfully intubated on the first attempt. }\end{array}$ & & $\mathbf{X}$ & \\
\hline $\begin{array}{l}\text { 6) Were all the patients who entered the trial properly } \\
\text { accounted for at its conclusion? } \\
\text { Yes. All were accounted for. }\end{array}$ & $\mathbf{X}$ & & \\
\hline $\begin{array}{l}\text { 7) How large was the treatment effect? } \\
\text { No treatment effect was reported. }\end{array}$ & & & $\mathbf{X}$ \\
\hline $\begin{array}{l}\text { 8) How precise was the estimate of the treatment effect? } \\
\text { No treatment effect was reported. However, the silver-coated } \\
\text { ETTs significantly reduced bacterial colonization within the } \\
\text { ventilator tubing and lower respiratory tract of the } \\
\text { intervention group compared to the control group. }\end{array}$ & & & $\mathrm{X}$ \\
\hline
\end{tabular}


Additionally, no bacteria were found within the lumen of the silver-coated ETTs while three of the standard ETTs were found to have bacterial colonization. Subjects with standard ETTs were found to have colonization of the lower respiratory tract and the ventilator tubing was extensively colonized.

9) Can the results be applied in your context or to the local population?

Can't tell. The data and results align with comparable studies used for this systematic review. However, the subjects are non-human so the results are less valuable than similar studies that used human subjects.

10) Were all clinically important outcomes considered?

Can't tell. The main outcome was identified and answered by the authors. However, the subjects were euthanized following the study which eliminated the possibility of developing VAP. While the authors were able to present data showing a reduction in colonization, the study stops short of showing a reduction in VAP development with the use of silver-coated ETTs.

11) Are the benefits worth the harms and costs?

Can't tell. The study, conducted and approved by the National Institutes of Health, does provide useful data for 
future researchers regarding antimicrobial effects of silvercoated ETTs. However, healthy animal subjects were used for this study and ultimately euthanized. The ethicality of animal research is an individual decision. 
Table B-3

Rello, J., Kollef, M., Diaz, E., Sandiumenge, A., del Castillo, Y., Corbella, X., \&

Zachskorn, R. (2006). Reduced burden of bacterial airway colonization with a novel silver-coated endotracheal tube in a randomized multiple-center feasibility study. Critical Care Medicine, 34(11), 2766-2772.

\begin{tabular}{|l|l|l|l|}
\hline Question & Yes & Can't & No \\
1) Did the review address a clearly focused question? & X & & \\
Yes. The question the study addressed was whether a silver- & & & \\
coated ETT could feasibly and safely reduce bacterial & & \\
colonization of the lungs and tracheal aspirates. The study \\
focused on ICU patients that were intubated for a minimum \\
of 24 hours. The results suggested the silver-coated ETT \\
offered delayed microbial colonization compared to standard \\
ETT (P .02). Additionally, the silver-coated ETT showed \\
validated software. The study was a prospective, randomized \\
controlled trial that utilized allocation concealment. The
\end{tabular}




\begin{tabular}{|c|c|c|}
\hline $\begin{array}{l}\text { study was a single blind study conducted at four hospitals, } \\
\text { three in Spain and one in the United States. } N=155 \text {. Of the } \\
155,121 \text { were intubated for a minimum of } 24 \text { hours. }\end{array}$ & & \\
\hline $\begin{array}{l}\text { 3) Were patients, health workers, and study personnel } \\
\text { blinded? } \\
\text { No. Both the microbiological lab personnel and the } \\
\text { investigators were blinded. Investigators were blinded to } \\
\text { block length and the microbiology lab was blinded to the } \\
\text { control/intervention groups. However, the ICU staff may } \\
\text { have been biased due to inability to "blind" them as the ETTs } \\
\text { were slightly different in appearance (silver-coating). } \\
\text { Additionally, there was no "blinding" of outcome assessment } \\
\text { which could have lead to potential detection bias. }\end{array}$ & & $\mathbf{X}$ \\
\hline $\begin{array}{l}\text { 4) Were the groups similar at the start of the trial? } \\
\text { Can't tell. Baseline characteristics and demographics were } \\
\text { similar in both groups. All patients were free of respiratory } \\
\text { infections, bronchiectasis, hematemesis, hemoptysis, cystic } \\
\text { fibrosis, immunosuppression, and exhibited no allergy to } \\
\text { silver compounds. All patients/legally authorized } \\
\text { representative were required to sign an informed consent } \\
\text { prior to beginning the study. However, the indication for } \\
\text { intubation was not consistent for all patients and could } \\
\text { impact patient prognosis/study outcomes. }\end{array}$ & $\mathbf{X}$ & \\
\hline
\end{tabular}




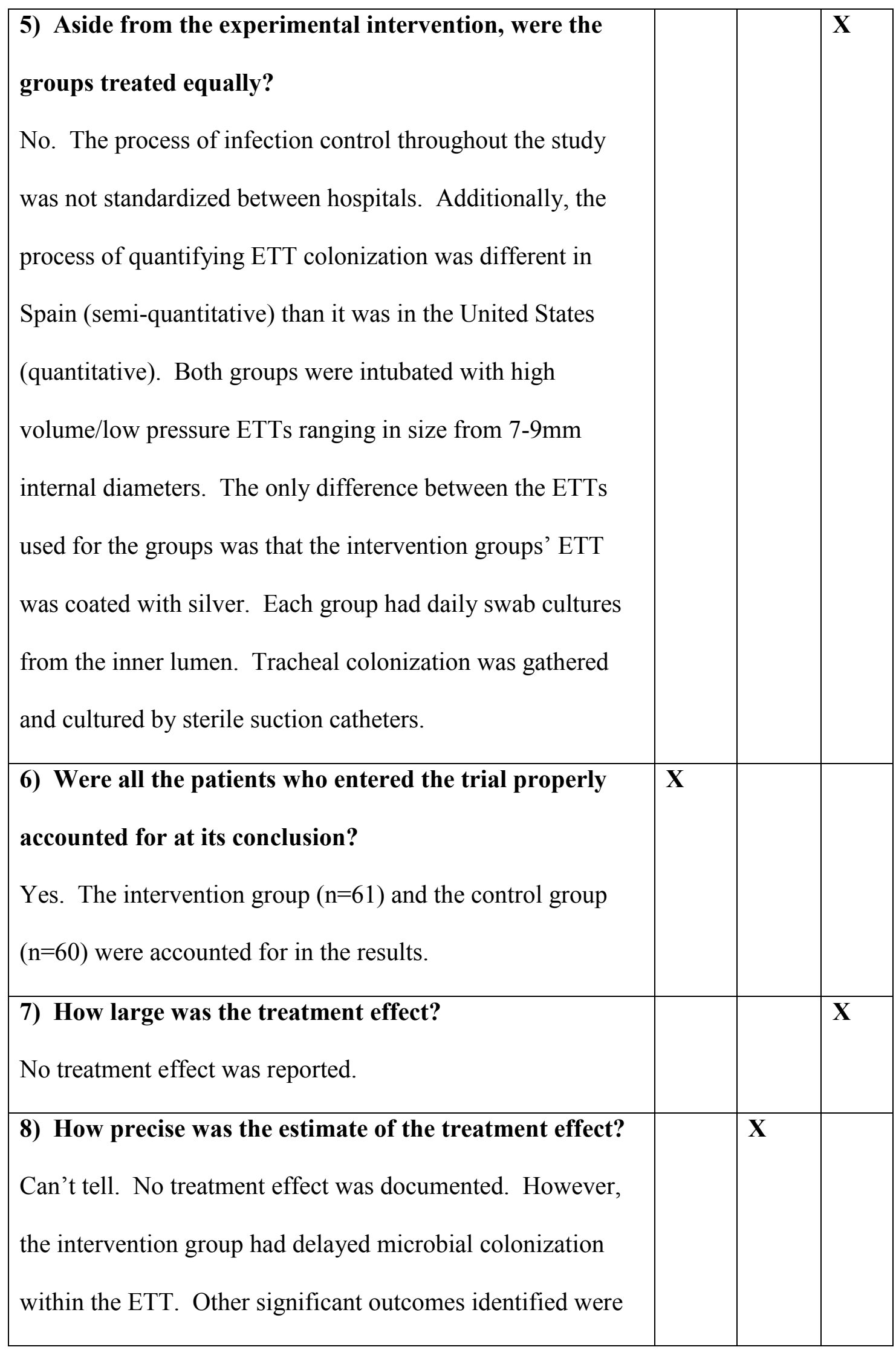




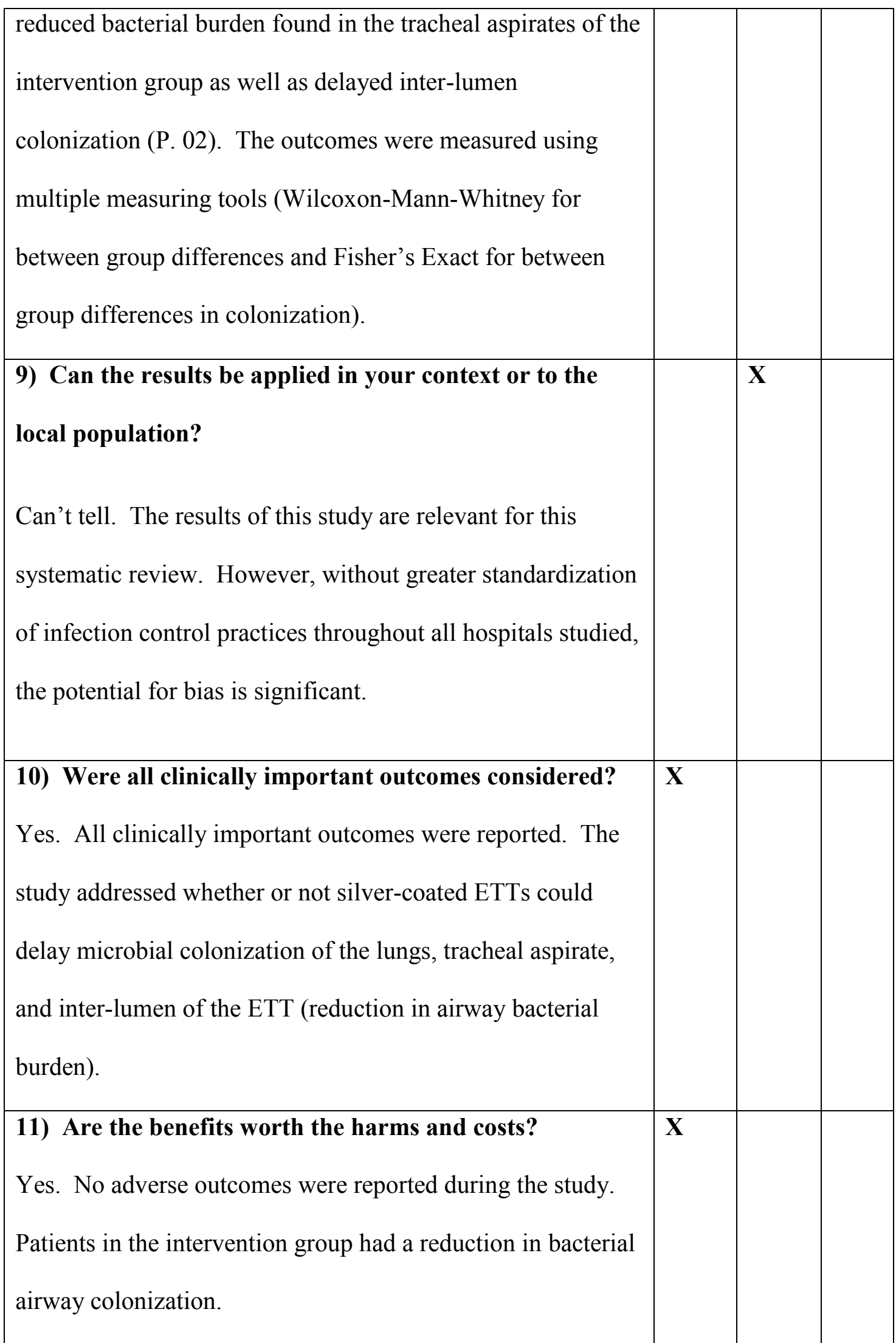

Table B-4. 
Kollef, M. H., Afessa, B., Anzueto, A., Veremakis, C., Kerr, K. M., Margolis, B. D., ... \& Restrepo, M. I. (2008). Silver-coated endotracheal tubes and incidence of ventilatorassociated pneumonia: the NASCENT randomized trial. JAMA, 300(7), 805-813.

\begin{tabular}{|c|c|c|c|}
\hline Question & Yes & $\begin{array}{l}\text { Can't } \\
\text { Tell }\end{array}$ & No \\
\hline $\begin{array}{l}\text { 1) Did the review address a clearly focused question? } \\
\text { Yes. The trial addressed the question of whether or not a } \\
\text { silver-coated ETT would reduce the incidence of } \\
\text { microbiologically confirmed VAP. }\end{array}$ & $\mathbf{X}$ & & \\
\hline $\begin{array}{l}\text { Was the assignment of patients to treatments } \\
\text { randomized? } \\
\text { Yes. The trial was a prospective, randomized, single-blind } \\
\text { controlled study. The study was conducted at } 54 \text { medical } \\
\text { centers throughout North America. Each medical center's } \\
\text { institutional review board approved the study. Screening for } \\
\text { the trial involved } 9417 \text { patients. Of the } 9417 \text {, } 7414 \text { were } \\
\text { excluded because they were either unable to consent or were } \\
\text { unlikely to require more than } 24 \text { hours of mechanical } \\
\text { ventilation. N= } 2003 \text { were randomized and expected to } \\
\text { require intubation and mechanical ventilation for a minimum } \\
\text { of } 24 \text { hours. Groups were randomly selected (control vs }\end{array}$ & $\mathbf{X}$ & & \\
\hline
\end{tabular}




\begin{tabular}{|c|c|c|}
\hline $\begin{array}{l}\text { intervention) by validated software. The control group } \\
\text { contained } n=743 \text {. The intervention group contained } n=766 \text {. }\end{array}$ & & \\
\hline $\begin{array}{l}\text { Were patients, health workers, and study personnel } \\
\text { blinded? } \\
\text { Yes. All microbiology lab personnel and study investigators } \\
\text { were blinded to the control/intervention groups as well as the } \\
\text { data and specifics related to their hospitalization. }\end{array}$ & $\mathbf{X}$ & \\
\hline $\begin{array}{l}\text { Were the groups similar at the start of the trial? } \\
\text { Yes. All participants of the study were at least } 18 \text { years old. } \\
\text { Mean age of the intervention group was } 60.9 \text {. Mean age of } \\
\text { the control group was } 62 \text {. Exclusions included current } \\
\text { enrollment in another study that could conflict with this one, } \\
\text { cystic fibrosis, pregnancy, previous intubation within the past } \\
30 \text { days, severe hemoptysis, and sensitivity to silver products. } \\
\text { Both groups had similar patient co-morbidities including } \\
\text { COPD, smoking, emergent surgery, trauma, and } \\
\text { immunodeficiency. }\end{array}$ & $\mathbf{X}$ & \\
\hline $\begin{array}{l}\text { 5) Aside from the experimental intervention, were the } \\
\text { groups treated equally? } \\
\text { Can't tell. The study does not detail specifics regarding } \\
\text { patient care. The study does detail specific patient data that } \\
\text { was collected such as BAL via tracheal suctioning, oral care, } \\
\text { daily chest radiographs, vital signs, and clinical signs of }\end{array}$ & & $\mathbf{X}$ \\
\hline
\end{tabular}




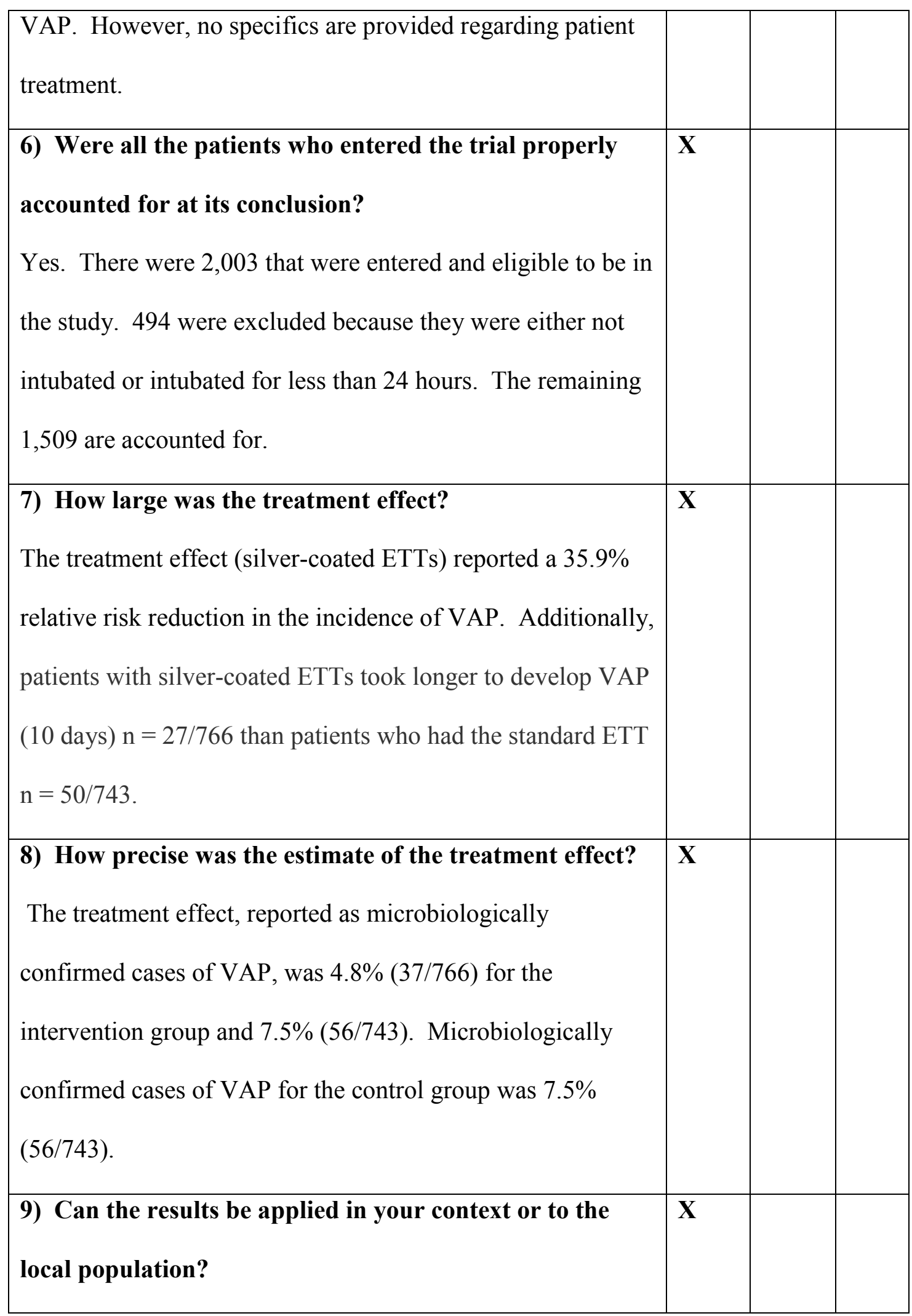




\begin{tabular}{|l|l|l|}
\hline Yes. The trial concluded that silver-coated ETTs offered & & \\
significant reductions in both the incidence of VAP and & & \\
delayed the onset of a VAP diagnosis when compared to & & \\
standard ETTs. & & \\
\hline 10) Were all clinically important outcomes considered? & $\mathbf{X}$ & \\
reported. The main outcome (diagnosis of VAP) and onset & & \\
were identified and clearly stated. Demographics and & & \\
baseline characteristics for both the control group and the & & \\
intervention group were presented in table format-making it & & \\
easy for the reader to visualize and interpret. & & \\
11) Are the benefits worth the harms and costs? & & \\
benefits exceed the harms and costs of the trial. & & \\
\hline
\end{tabular}


Table B-5.

Afessa, B., Shorr, A. F., Anzueto, A. R., Craven, D. E., Schinner, R., \& Kollef, M. H. (2010). Association between a silver-coated endotracheal tube and reduced mortality in patients with ventilator-associated pneumonia. CHEST Journal, 137(5), 1015-1021.

\begin{tabular}{|l|l|l|l|}
\hline \multicolumn{1}{|c|}{ Question } & Yes & Can't & No \\
1) Did the review address a clearly focused question? & X & & \\
Yes. The review questioned whether or not there was an & & & \\
association between silver-coated ETTs and reduced & & & \\
mortality for patients who developed VAP. Mortality was & & & \\
reduced in VAP patients from 20/56 (36\%) in control group) & & & \\
to 5/37 (14\%) in the intervention group) N=93. & & & \\
\hline 2) Was the assignment of patients to treatments & & & \\
randomized? & & & \\
Yes. This was a retrospective cohort analysis or the & & & \\
NASCENT study (patients were randomized for the & & & \\
NASCENT study). & & & \\
\hline 3) Were patients, health workers, and study personnel & X & & \\
\hline
\end{tabular}




\begin{tabular}{|c|c|c|}
\hline $\begin{array}{l}\text { groups. Additionally, they followed antibiotic guidelines for } \\
\text { empirical antibiotic therapy for VAP patients. }\end{array}$ & & \\
\hline $\begin{array}{l}\text { 4) Were the groups similar at the start of the trial? } \\
\text { Yes. There were no statistically significant differences in } \\
\text { demographics or risk factors between the control group and } \\
\text { intervention group. Each group had approximately the same } \\
\text { percentage of patients with pre-existing conditions such as } \\
\text { COPD, immunodeficiency, trauma, emergent surgeries, } \\
\text { inappropriate administration of antibiotics, and coma. }\end{array}$ & $\mathbf{X}$ & \\
\hline $\begin{array}{l}\text { 5) Aside from the experimental intervention, were the } \\
\text { groups treated equally? } \\
\text { Can't tell. There are not details on frequency of antibiotics, } \\
\text { VAP bundles, types of medications given during intubation } \\
\text { and ventilation, or preventative strategies. }\end{array}$ & & $\mathbf{X}$ \\
\hline $\begin{array}{l}\text { 6) Were all the patients who entered the trial properly } \\
\text { accounted for at its conclusion? } \\
\text { Yes. There were } \mathrm{N}=93 \text { patients identified and studied during } \\
\text { this retrospective cohort analysis. The control group } \\
\text { included } 56 \text { and the intervention group } 37 \text {. }\end{array}$ & $\mathbf{X}$ & \\
\hline $\begin{array}{l}\text { 7) How large was the treatment effect? } \\
\text { There was no specific mention of the treatment effect. } \\
\text { However, group designation was a predictor of mortality and }\end{array}$ & & $\mathbf{X}$ \\
\hline
\end{tabular}




\begin{tabular}{|c|c|c|}
\hline $\begin{array}{l}\text { silver-coated ETTs were associated with reduced mortality } \\
\text { rates for patients with VAP. }\end{array}$ & & \\
\hline $\begin{array}{l}\text { 8) How precise was the estimate of the treatment effect? } \\
\text { The predictor of mortality given by an odds ratio was } 95 \% \\
\text { confidence interval when comparing silver-coated ETTs to } \\
\text { standard ETTs. }\end{array}$ & & $\mathbf{X}$ \\
\hline $\begin{array}{l}\text { 9) Can the results be applied in your context or to the } \\
\text { local population? } \\
\text { Yes. These results directly apply to this systematic review. } \\
\text { The results are derived from the "hallmark study" in this } \\
\text { research, the NASCENT study. }\end{array}$ & $\mathbf{X}$ & \\
\hline $\begin{array}{l}\text { 10) Were all clinically important outcomes considered? } \\
\text { Can't tell. While mortality was the primary outcome } \\
\text { identified throughout the study, the authors cite limitations } \\
\text { within their study by not presenting any proof of "cause and } \\
\text { effect" with the silver-coated ETTs and reduced patient } \\
\text { mortality. There may have been unidentified risk factors } \\
\text { (cause) that contributed to the pathophysiologic demise } \\
\text { (effect) of patients in one or both groups (control and } \\
\text { intervention). }\end{array}$ & & $\mathbf{X}$ \\
\hline $\begin{array}{l}\text { 11) Are the benefits worth the harms and costs? } \\
\text { Yes. Only patients able to consent were included for this } \\
\text { study. In the absence of this research, all of these patients }\end{array}$ & $\mathbf{X}$ & \\
\hline
\end{tabular}


would have been intubated with standard ETTs. This study identified a $60 \%$ reduction in the mortality rate for patients with silver-coated ETTs who developed VAP compared to the standard ETTs (control group). 


\section{Appendix C}

\section{Critical Appraisal for Summaries of Evidence (CASE) Worksheet for Individual Studies}

Table C-1.

Berra, L., De Marchi, L., Yu, Z. X., Laquerriere, P., Baccarelli, A., \& Kolobow, T.

(2004). Endotracheal tubes coated with antiseptics decrease bacterial colonization of the ventilator circuits, lungs, and endotracheal tube. Anesthesiology: The Journal of the American Society of Anesthesiologists, 100(6), 1446-1456.

\begin{tabular}{|l|l|}
\hline \multicolumn{2}{|l|}{ Critical Appraisal for Summaries of Evidence (CASE) Worksheet } \\
\hline Questions & Evaluation \\
\hline Summary Topic & Yes \\
\hline $\begin{array}{l}\text { Is the summary specific in scope and } \\
\text { application? }\end{array}$ & Yes \\
\hline Summary Methods & Yes \\
\hline $\begin{array}{l}\text { Is the authorship of the summary } \\
\text { transparent? }\end{array}$ & $\begin{array}{l}\text { Yre the reviewer(s)/editor(s) of the } \\
\text { summary transparent? }\end{array}$ \\
\hline $\begin{array}{l}\text { Are the research methods transparent and } \\
\text { comprehensive? }\end{array}$ & Yes \\
\hline $\begin{array}{l}\text { Is the evidence grading system transparent } \\
\text { and translatable? }\end{array}$ & Yes \\
\hline Summary Content & Not completely \\
\hline Are the recommendations clear? & Yes \\
\hline $\begin{array}{l}\text { Are the recommendations appropriately } \\
\text { cited? }\end{array}$ & No \\
\hline Are the recommendations current? & Yes \\
\hline \begin{tabular}{l} 
Is the summary unbiased? \\
\hline Summary Application
\end{tabular} \\
\hline $\begin{array}{l}\text { Can this summary be applied to your } \\
\text { patient(s)? }\end{array}$ & No \\
\hline
\end{tabular}


Table C-2.

Berra, L., Kolobow, T., Laquerriere, P., Pitts, B., Bramati, S., Pohlmann, J., ... \&

Baccarelli, A. (2008). Internally coated endotracheal tubes with silver sulfadiazine in polyurethane to prevent bacterial colonization: a clinical trial. Intensive Care

Medicine, 34(6), 1030.

\begin{tabular}{|l|l|}
\hline \multicolumn{2}{|l|}{ Critical Appraisal for Summaries of Evidence (CASE) Worksheet } \\
\hline Questions & Evaluation \\
\hline Summary Topic & Yes \\
\hline $\begin{array}{l}\text { Is the summary specific in scope and } \\
\text { application? }\end{array}$ & Yes \\
\hline Summary Methods & Yes \\
\hline $\begin{array}{l}\text { Is the authorship of the summary } \\
\text { transparent? }\end{array}$ & Yes \\
\hline $\begin{array}{l}\text { Are the reviewer(s)/editor(s) of the } \\
\text { summary transparent? }\end{array}$ & Yes \\
\hline $\begin{array}{l}\text { Are the research methods transparent and } \\
\text { comprehensive? }\end{array}$ & $\begin{array}{l}\text { Is the evidence grading system transparent } \\
\text { and translatable? }\end{array}$ \\
\hline Summary Content & Yes \\
\hline \begin{tabular}{l} 
Are the recommendations clear? \\
\hline $\begin{array}{l}\text { Are the recommendations appropriately } \\
\text { cited? }\end{array}$
\end{tabular} & Yes \\
\hline Are the recommendations current? & Not completely \\
\hline Is the summary unbiased? & Yes \\
\hline Summary Application & Not completely \\
\hline $\begin{array}{l}\text { Can this summary be applied to your } \\
\text { patient(s)? }\end{array}$ & \\
\hline
\end{tabular}


Table C-3.

Rello, J., Kollef, M., Diaz, E., Sandiumenge, A., del Castillo, Y., Corbella, X., \&

Zachskorn, R. (2006). Reduced burden of bacterial airway colonization with a novel

silver-coated endotracheal tube in a randomized multiple-center feasibility study. Critical

Care Medicine, 34(11), 2766-2772

\begin{tabular}{|c|c|}
\hline \multicolumn{2}{|c|}{ Critical Appraisal for Summaries of Evidence (CASE) Worksheet } \\
\hline Questions & Evaluation \\
\hline \multicolumn{2}{|l|}{$\overline{\text { Summary Topic }}$} \\
\hline $\begin{array}{l}\text { Is the summary specific in scope and } \\
\text { application? }\end{array}$ & Yes \\
\hline \multicolumn{2}{|l|}{ Summary Methods } \\
\hline $\begin{array}{l}\text { Is the authorship of the summary } \\
\text { transparent? }\end{array}$ & Yes \\
\hline $\begin{array}{l}\text { Are the reviewer(s)/editor(s) of the } \\
\text { summary transparent? }\end{array}$ & Not completely \\
\hline $\begin{array}{l}\text { Are the research methods transparent and } \\
\text { comprehensive? }\end{array}$ & Not completely \\
\hline $\begin{array}{l}\text { Is the evidence grading system transparent } \\
\text { and translatable? }\end{array}$ & Yes \\
\hline \multicolumn{2}{|l|}{ Summary Content } \\
\hline Are the recommendations clear? & Yes \\
\hline $\begin{array}{l}\text { Are the recommendations appropriately } \\
\text { cited? }\end{array}$ & Yes \\
\hline Are the recommendations current? & No \\
\hline Is the summary unbiased? & Yes \\
\hline \multicolumn{2}{|l|}{ Summary Application } \\
\hline $\begin{array}{l}\text { Can this summary be applied to your } \\
\text { patient(s)? }\end{array}$ & Not completely \\
\hline
\end{tabular}


Table C-4.

Kollef, M. H., Afessa, B., Anzueto, A., Veremakis, C., Kerr, K. M., Margolis, B. D., ... \&

Restrepo, M. I. (2008). Silver-coated endotracheal tubes and incidence of ventilator-

associated pneumonia: the NASCENT randomized trial. JAMA, 300(7), 805-813.

\begin{tabular}{|l|l|}
\hline \multicolumn{2}{|l|}{ Critical Appraisal for Summaries of Evidence (CASE) Worksheet } \\
\hline Questions & Evaluation \\
\hline Summary Topic & Yes \\
\hline $\begin{array}{l}\text { Is the summary specific in scope and } \\
\text { application? }\end{array}$ & Yes \\
\hline Summary Methods & Yes \\
\hline $\begin{array}{l}\text { Is the authorship of the summary } \\
\text { transparent? }\end{array}$ & Not completely \\
\hline $\begin{array}{l}\text { Are the reviewer(s)/editor(s) of the } \\
\text { summary transparent? }\end{array}$ & Not completely \\
\hline $\begin{array}{l}\text { Are the research methods transparent and } \\
\text { comprehensive? }\end{array}$ & $\begin{array}{l}\text { Is the evidence grading system transparent } \\
\text { and translatable? }\end{array}$ \\
\hline Summary Content & Yes \\
\hline Are the recommendations clear? & Yes \\
\hline $\begin{array}{l}\text { Are the recommendations appropriately } \\
\text { cited? }\end{array}$ & Not completely \\
\hline Are the recommendations current? & Yes \\
\hline Is the summary unbiased? & Yes \\
\hline Summary Application & $\begin{array}{l}\text { Can this summary be applied to your } \\
\text { patient(s)? }\end{array}$ \\
\hline
\end{tabular}


Table C-5

Afessa, B., Shorr, A. F., Anzueto, A. R., Craven, D. E., Schinner, R., \& Kollef, M. H.

(2010). Association between a silver-coated endotracheal tube and reduced mortality in

patients with ventilator-associated pneumonia. CHEST Journal, 137(5), 1015-1021.

\begin{tabular}{|c|c|}
\hline \multicolumn{2}{|c|}{ Critical Appraisal for Summaries of Evidence (CASE) Worksheet } \\
\hline Questions & Evaluation \\
\hline \multicolumn{2}{|l|}{ Summary Topic } \\
\hline $\begin{array}{l}\text { Is the summary specific in scope and } \\
\text { application? }\end{array}$ & Yes \\
\hline \multicolumn{2}{|l|}{ Summary Methods } \\
\hline $\begin{array}{l}\text { Is the authorship of the summary } \\
\text { transparent? }\end{array}$ & Yes \\
\hline $\begin{array}{l}\text { Are the reviewer(s)/editor(s) of the } \\
\text { summary transparent? }\end{array}$ & Yes \\
\hline $\begin{array}{l}\text { Are the research methods transparent and } \\
\text { comprehensive? }\end{array}$ & Yes \\
\hline $\begin{array}{l}\text { Is the evidence grading system transparent } \\
\text { and translatable? }\end{array}$ & No \\
\hline \multicolumn{2}{|l|}{ Summary Content } \\
\hline Are the recommendations clear? & Yes \\
\hline $\begin{array}{l}\text { Are the recommendations appropriately } \\
\text { cited? }\end{array}$ & Yes \\
\hline Are the recommendations current? & Yes \\
\hline Is the summary unbiased? & Yes \\
\hline \multicolumn{2}{|l|}{ Summary Application } \\
\hline $\begin{array}{l}\text { Can this summary be applied to your } \\
\text { patient(s)? }\end{array}$ & No \\
\hline
\end{tabular}




\section{Appendix D \\ Critical Appraisal for Summaries of Evidence (CASE) Worksheet \\ for Cross Study Analysis}

\begin{tabular}{|c|c|}
\hline \multicolumn{2}{|c|}{$\begin{array}{l}\text { Critical Appraisal for Summaries of Evidence (CASE) Worksheet } * \text { Numbers in } \\
\text { evaluation correspond with those assigned to articles in data extrapolation chart }\end{array}$} \\
\hline Questions & Evaluation \\
\hline \multicolumn{2}{|l|}{$\overline{\text { Summary Topic }}$} \\
\hline $\begin{array}{l}\text { Is the summary specific in scope and } \\
\text { application? }\end{array}$ & $\begin{array}{l}\text { Yes- } 1,2,3,4,5 \\
\text { Not completely- } \\
\text { No- }\end{array}$ \\
\hline \multicolumn{2}{|l|}{ Summary Methods } \\
\hline $\begin{array}{l}\text { Is the authorship of the summary } \\
\text { transparent? }\end{array}$ & $\begin{array}{l}\text { Yes- } 1,2,3,4,5 \\
\text { Not completely- } \\
\text { No- }\end{array}$ \\
\hline $\begin{array}{l}\text { Are the reviewer(s)/editor(s) of the } \\
\text { summary transparent? }\end{array}$ & $\begin{array}{l}\text { Yes- } 1,2,4,5 \\
\text { Not completely- } 3 \\
\text { No- }\end{array}$ \\
\hline $\begin{array}{l}\text { Are the research methods transparent and } \\
\text { comprehensive? }\end{array}$ & $\begin{array}{l}\text { Yes- } 1,2,5 \\
\text { Not completely- } 3,4 \\
\text { No- }\end{array}$ \\
\hline $\begin{array}{l}\text { Is the evidence grading system transparent } \\
\text { and translatable? }\end{array}$ & $\begin{array}{l}\text { Yes- } 1,2,3 \\
\text { Not completely- } 4 \\
\text { No- } 5\end{array}$ \\
\hline \multicolumn{2}{|l|}{ Summary Content } \\
\hline Are the recommendations clear? & $\begin{array}{l}\text { Yes- } 2,3,4,5 \\
\text { Not completely-1 } \\
\text { No- }\end{array}$ \\
\hline $\begin{array}{l}\text { Are the recommendations appropriately } \\
\text { cited? }\end{array}$ & $\begin{array}{l}\text { Yes- } 1,2,3,4,5 \\
\text { Not completely- } \\
\text { No- }\end{array}$ \\
\hline Are the recommendations current? & $\begin{array}{l}\text { Yes- } 5 \\
\text { Not completely- } 2,4 \\
\text { No- } 1,3\end{array}$ \\
\hline Is the summary unbiased? & $\begin{array}{l}\text { Yes- } 1,2,3,4,5 \\
\text { Not completely } \\
\text { No }\end{array}$ \\
\hline \multicolumn{2}{|l|}{ Summary Application } \\
\hline $\begin{array}{l}\text { Can this summary be applied to your } \\
\text { patient(s)? }\end{array}$ & $\begin{array}{l}\text { Yes- } 4 \\
\text { Not completely- } 2,3 \\
\text { No- } 1,5\end{array}$ \\
\hline
\end{tabular}

